\title{
The Effect of Hot Treatment on Composition and Microstructure of HVOF Iron Aluminide Coatings in $\mathrm{Na}_{2} \mathrm{SO}_{4}$ Molten Salts
}

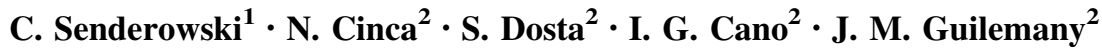

Submitted: 16 November 2018/in revised form: 25 May 2019/Published online: 8 July 2019

(C) The Author(s) 2019

\begin{abstract}
The paper deals with the hot corrosion performance of FeAl base intermetallic HVOF coatings in molten $\mathrm{Na}_{2} \mathrm{SO}_{4}$ at $850{ }^{\circ} \mathrm{C}$ in an isothermal process over the span of $45 \mathrm{~h}$ under static conditions. The test was validated with electron microscopy and compositional analyses in the cross-section area, as well as x-ray diffraction techniques. All the coatings were characterized by Al-depleted regions, intersplat oxidation and different stoichiometric ratios of iron aluminides. The results were discussed in relation to the formation of oxide scales on the surface after exposition to corrosive media, as well as heterogeneity and defects of the sprayed coatings. The Fe40Al (at.\%) powder showed quite uniform phase distribution after spraying and preserved its integrity after corrosion test; the $\mathrm{FeCr}$ $25 \%+\mathrm{FeAl}-\mathrm{TiAl}-\mathrm{Al}_{2} \mathrm{O}_{3}$ (wt. \%) and $\mathrm{Fe} 46 \mathrm{Al}-6.55 \mathrm{Si}$ (at.\%) powders exhibited interface oxidation, with localized corrosion attacks proceeding through particle boundaries and microcrack networks with no evidence of $\mathrm{Na}$ and $\mathrm{S}$ penetration. $\mathrm{Fe}_{x} \mathrm{Al}_{y}$ alloys are susceptible to accelerated damage and decohesion of the coating, whereas the formation of sulfides is observed at certain points.
\end{abstract}

Keywords FeAl intermetallic $\cdot$ hot corrosion · thermal spray coatings

C. Senderowski

cezary.senderowski@uwm.edu.pl

1 Department of Materials Technology and Machinery, University of Warmia and Mazury, M. Oczapowskiego 11 St, 10-719 Olsztyn, Poland

2 Dpt. Ciència dels Materials i Enginyeria Metallúrgica, Centre de Projecció Tèrmica (CPT), Universitat de Barcelona, Martí i Franquès 1, 08028 Barcelona, Spain

\section{Introduction}

High-temperature oxidation is believed to be the major reason for the degradation of materials used at elevated temperatures, which in consequence leads to prolonged downtime of elements such as boilers and turbines utilized in power production (Ref 1-4). As an adequate countermeasure to the above-mentioned issues, intermetallics and $\mathrm{Ni}$-based alloys have gained significant attraction as coating materials (Ref 1-3, 5-7).

Transition metal aluminides, mainly those based on $\mathrm{Ni}$ and $\mathrm{Fe}$, are potentially applicable at high temperatures and provide a sufficient alternative to superalloys (Ref 4-6, 812). The alumina layer, formed on the surface of materials, is responsible for their excellent resistance to oxidizing, sulfiding and carburizing atmospheres even at temperatures exceeding $1000{ }^{\circ} \mathrm{C}(\operatorname{Ref} 5,10,13)$.

However, while showing good strength and environmental stability, other aspects such as poor ductility and toughness at room temperature, mediocre creep strength, as well as fabrication difficulties have greatly hindered the introduction of intermetallics as industrial structural materials (Ref 14). Therefore, their commercial application in some fields is still a matter of concern (Ref 15).

The applications of iron aluminides are, for the most part, based on their excellent corrosion resistance at high temperatures in environments that cause damage to $\mathrm{Fe}-\mathrm{Cr}$ $\mathrm{Ni}$ steels and other alloys (Ref 4). They show higher resistance to sulfidation and carburizing atmospheres, as well as to molten nitrates and carbonate salts in relation to multiple different iron- or nickel-based alloys (Ref 16, 17). $\mathrm{FeAl}$ alloys have demonstrated particularly improved resistance to various molten salts leading to hot corrosion in heat exchanging systems, incinerators and burners. This pertains to such chemicals as potassium sulfate $\left(\mathrm{K}_{2} \mathrm{SO}_{4}\right)$, 
vanadium pentoxide $\left(\mathrm{V}_{2} \mathrm{O}_{5}\right)$, mixtures of sodium sulfate and vanadium pentoxide $\left(\mathrm{Na}_{2} \mathrm{SO}_{4}-\mathrm{V}_{2} \mathrm{O}_{5}\right)$, chlorates and carbonates, all of which can inflict severe damage in the energy sector (Ref 18-24).

High resistance to hot corrosion is a matter of paramount importance in many branches of industry concerning the construction of boilers, internal combustion engines, gas turbines, fluidized bed combustion and industrial waste incinerators. The material degradation is determined by the confluence of high-temperature oxidation, hot corrosion and erosion processes (Ref 1-3, 5-7, 11, 12, 25, 26).

However, iron aluminide corrosion resistance extends to temperatures at which these alloys exhibit limited or poor mechanical strength. Therefore, in many cases, they may be better utilized as clads or coatings for anti-corrosion protection, owing to their limited strength at elevated temperatures (Ref 26-30).

Numerous thermal spray techniques, most notably plasma spraying (Ref 28, 31, 32), high-velocity oxy-fuel (HVOF) (Ref 17, 27, 28, 33-47) and D-gun spraying processes (Ref 26, 29, 48-59) are considered for Fe-Al intermetallic coating materials. In comparison with other industrially used coatings such as CVD, PVD and hard chromium plating, a much thicker coating can be obtained by thermal spraying, which is a prerequisite in the energy sector. High-velocity arc spraying process (HVAS), a technique used to deposit Fe-Al intermetallic and Fe-Al/ WC protective coatings, was designed for evaporator pipes subjected to corrosive and erosive influence of vapor at $550{ }^{\circ} \mathrm{C}$ and serves as an example, especially through the prism of their application in the Chinese industry (Ref 60).

Among thermal spray techniques, the scientists, manufacturers and global investors show much interest in HVOF, a state-of-the-art thermal spray technology, which not only yields positive results, but also is relatively cheap (Ref 3, 17, 26, 28, 33-47).

Thermal spray iron aluminide coatings were previously tested in high-temperature gaseous environments (Ref $17,36,37,47,61$ ), but to the best of the authors' knowledge, very few findings concerning their use under hot corrosion conditions were made (Ref 62). These authors report that no degradation (corrosion and wear) was noticed on the surface of the Fe-25\% Al-Zr (wt.\%) plasma and HVOF coatings sprayed onto low-carbon steel heat exchanger tubes, which were tested in a new industrial plant burning fuel of very poor quality. However, their research was not orientated toward the coating structures and corrosion evolution.

On the other hand, Singh Sidhu et al. 63 studied the corrosion of plasma-sprayed $\mathrm{Ni}_{3} \mathrm{Al}$ coatings in air and molten salt $\left(\mathrm{Na}_{2} \mathrm{SO}_{4}-60 \% \mathrm{~V}_{2} \mathrm{O}_{5}\right)$ at $900{ }^{\circ} \mathrm{C}$ on low-carbon steel substrates of extended application in boilers.
Other thermal spray coatings, widely studied in terms of hot corrosion protection resistance, are the case of plasma spraying of MCrAlY's in TBC systems for aviation gas turbines purposes, which notably reduces their longevity under severe conditions involving molten sulfate-vanadate deposits (Ref 64-68). These coatings can be alternatively produced by HVOF process, which utilizes high-pressure combustion of oxygen and fuel to obtain a relatively low temperature of a supersonic gas jet in comparison with plasma spraying. HVOF allows us to obtain denser and less oxidized coatings, which are more resistant to corrosion (Ref 69).

The growing interest in the promising properties of intermetallic alloys based on the $\mathrm{Fe}-\mathrm{Al}$ equilibrium phase diagram contributed to the gradual development of the HVOF spraying technique, which proved useful for the production of such intermetallic coatings in terms of their practical application on various steel elements, exposed to corrosive and erosive environment in the energy sector (Ref 28, 33-47, 70-74). The focus in these works was mostly placed on the structural properties of $\mathrm{Fe}-\mathrm{Al}$ coatings and their wear resistance under dry friction (in congruence with ASTM G99-03), abrasive wear (in accordance with ASTM G65-00) and erosive wear, along with the involvement of $\mathrm{Al}_{2} \mathrm{O}_{3}$ particles (Ref 44). Furthermore, the research involved the performance of $\mathrm{Fe}-\mathrm{Al}$ coatings under high-temperature oxidation conditions at 900, 1000 and $1100{ }^{\circ} \mathrm{C}$ - for 4,36 and $72 \mathrm{~h}$, respectively, in the atmospheric air (Ref 27).

Usitalo et al. 75 conducted studies on laser re-melting of HVOF-sprayed Ni-50Cr, Ni-57Cr, $\mathrm{Fe}_{3} \mathrm{Al}, \mathrm{Ni}-21 \mathrm{Cr}-9 \mathrm{Mo}$ coatings and reported that the above-mentioned coatings did not suffer from any corrosive damage, whereas sprayed coatings were penetrated by corrosive species.

Other HVOF and novel cold-spray coatings, such as $\mathrm{Cr}_{3} \mathrm{C}_{2}$-NiCr and WC-Co, are widely studied regarding their wear resistance behavior (Ref 1-3, 7, 25, 76) while great emphasis is placed upon hot corrosion-related applications. Iron aluminide intermetallics appear to provide interesting properties favorable to hot corrosion protection and also manifest wear resistance at high temperatures, providing competition to cobalt binder in WC-Co composites and Nibased superalloys (Ref 5, 6, 10-12, 60, 77-81).

Different alloying elements in iron aluminide and their effect on the oxide scales development when exposed to harsh environments have been investigated (Ref $17,38,42,72-74)$. In this regard, we propose the application of several feedstock iron aluminide powders obtained from different manufacturing routes.

Notably, Senderowski Ref (56) developed a new concept of nanocomposite $\mathrm{Fe}-\mathrm{Al}$ intermetallic coatings created in situ during gas detonation spraying out of powder with compounds from the Fe-Al phase diagram, manufactured 
by the self-decomposition method (Ref 57). It was assumed that those powders would exhibit sufficient plastic susceptibility under the spraying test conditions, acceptable mechanical properties of the coatings and good stability of the structure during high-temperature heating. The shortlisted properties of these powders are mostly related to reduced brittleness caused by dynamic oxidation at high temperatures (especially above $500{ }^{\circ} \mathrm{C}$ ), in the oxygen containing environment.

Particle size control of the self-decomposed powders, especially of the fraction below $80 \mu \mathrm{m}$, gives them a more prominent role in the HVOF spraying process. Furthermore, the price of self-decomposing powder is about three times lower than the price of powders of equivalent compositions, produced by gas atomization.

Therefore, after considering the potential advantages of the implementation of the self-decomposing intermetallic Fe-Al-type powders, the aim of the present research was twofold:

(i) developing several iron aluminide HVOF coatings from a Fe40Al (at.\%) and FeCr-25\% + FeAl-TiAl$\mathrm{Al}_{2} \mathrm{O}_{3}$ (wt.\%) powders and comparing them with self-decomposed and SHS (self-propagating hightemperature synthesis)-manufactured powders of different compositions and

(ii) evaluating the performance of these coatings in $\mathrm{Na}_{2} \mathrm{SO}_{4}$ molten salt at $850{ }^{\circ} \mathrm{C}$, as the ultimate solution for typical application in industrial boilers.

It is well known that the application area of the $\mathrm{FeAl}$ coatings depends on their extensive properties. On the basis of the comprehensive results of own research (Ref 59, 82) already conducted, a comprehensive analysis of the impact of the structure, the level of strengthening and the state of residual stress of $\mathrm{FeAl}$ coatings on their adhesive strength was carried out. The mechanism of residual stress generation in FeAl coating under supersonic D-gun spraying conditions was presented, with a multi-phase structure of $\mathrm{Fe}-\mathrm{Al}$ coatings and changes in the Young's modulus of the $\mathrm{FeAl}$ coating at elevated temperatures up to $900{ }^{\circ} \mathrm{C}$ taken into account. The mechanism of structure degradation of hybrid coating systems in different load states was subjected to an analysis by means of TAT (tensile adhesion test) and a three-dimensional bending test coupled with acoustic emission recording (Ref 82). The TAT test showed that the $\mathrm{FeAl}$ coating sprayed directly onto a steel substrate exhibits significantly lower adhesive strength, compared to hybrid coating systems of NiCr-20 or NiAl-5 sprayed onto the steel substrate before the $\mathrm{FeAl}$ base coating. The average adhesive strength of individual coating systems was, respectively: $\mathrm{FeAl} /$ steel-23 $\mathrm{MPa}$, $\mathrm{FeAl} / \mathrm{NiAl5} / \mathrm{steel}-31 \mathrm{MPa}$, NiAl5/steel and $\mathrm{NiCr} 20 /$ steel-33 MPa, and $\mathrm{FeAl} / \mathrm{NiCr} 20 /$ steel system $-37 \mathrm{MPa}$ (Ref 82).

Because we have already considered some aspects of the mechanical performance of the Fe-Al-type coatings, it is a good reason to focus in this paper on the phase and microstructural changes as the "corrosion performance" of the coatings at high temperature in an aggressive environment.

At the same time, the "corrosion performance" that we are studying makes reference to the qualitative phase and microstructural evolution of the coatings, without a quantitative evaluation of weight changes as oxidation dynamics, which is relatively simple for bulk materials. Such an analysis is not so simple in the case of the coating-substrate system, due to the strong oxidation of substrate material at high temperature, which does not lead to reliable results in regard to the $\mathrm{FeAl}$ coating itself.

Therefore, in this work, we focused on the analysis of structural stability during high-temperature oxidation at $850{ }^{\circ} \mathrm{C}$ in the aggressive $\mathrm{Na}_{2} \mathrm{SO}_{4}$ environment of assprayed $\mathrm{Fe}-\mathrm{Al}$ coatings, under the same HVOF process conditions with various types of alloy powders of different chemical composition.

\section{Experimental Procedure}

The nominal compositions and characteristics of the powders used in the tests are presented in Table 1. The commercial $\mathrm{FeAl}$ grade 3 with a near equiatomic composition, provided by Mecachrome (France), is a pre-alloyed, gas atomized and subsequently ball-milled powder (powder 1). Both powder 2 and powder 3 were produced in the Department of Materials Science of the Silesian Technical University by the self-decomposed method described in detail in Ref 57.

Powder 4 was also produced in the Department of Materials Science of the Silesian Technical University through the SHS technique, contained Fe-Al-type phases agreed upon as $\mathrm{Fe}_{x} \mathrm{Al}_{y}$. Their complex phase composition, properties and morphology were considered with a view to possible applications as protective coatings in the power industry sector.

The substrate material was a low-alloy carbon steel G41350 UNS (AISI 4135) of chemical composition presented in Table 2, in the form of coupons with dimensions of $50 \times 20 \times 5 \mathrm{~mm}$ which were grit-blasted $(\mathrm{Ra}=4 \mu \mathrm{m})$, directly before the HVOF spraying to provide mechanical bonding.

The equipment used for the spraying process was a Diamond Jet Hybrid (DJH2700) designed by SULZER METCO. The following spraying parameters were applied: $\mathrm{H}_{2}$ flow rate $=7171 \mathrm{~min}^{-1}$, oxygen flow 
Table 1 Iron aluminide feedstock powders characteristics

\begin{tabular}{llll}
\hline Powders & \multicolumn{1}{c}{ Nominal composition } & Particle size, $\mu \mathrm{m}$ & \multicolumn{1}{c}{ Method of manufacture } \\
\hline Powder 1 (FeAl grade 3) & $\mathrm{Fe}-40 \mathrm{Al}-0.05 \mathrm{Zr}\left(\right.$ at.\%) $+50 \mathrm{ppm} \mathrm{B}+1$ wt. $\% \mathrm{Y}_{2} \mathrm{O}_{3}$ & $<50$ & Ball milling \\
Powder 2 & $\mathrm{FeCr} 25\left(\right.$ wt.\%) $+\mathrm{FeAl}-\mathrm{TiAl}-\mathrm{Al}_{2} \mathrm{O}_{3}$ & $<60$ & \\
Powder 3 & $\mathrm{Fe} 46 \mathrm{Al}-6.55 \mathrm{Si}($ at.\%) & $<40$ & Self-decomposed \\
Powder 4 & $\mathrm{Fe}_{x} \mathrm{Al}_{y}$ & $-53+38$ & $\mathrm{SHS}_{\text {multi-phases Fe }} \mathrm{Al}_{y}$ type powder \\
\hline
\end{tabular}

Table 2 Chemical composition of substrate material

\begin{tabular}{lcccccc}
\hline Chemical composition & \multicolumn{6}{c}{ Content, wt.\% } \\
\cline { 2 - 7 } & $\mathrm{Fe}$ & $\mathrm{Cr}$ & $\mathrm{Mn}$ & $\mathrm{Si}$ & $\mathrm{Mo}$ & $\mathrm{C}$ \\
\hline G41350 UNS (AISI 4135) & 97.33 & 0.80 & 0.70 & 0.15 & 0.15 & 0.33 \\
Alloy steel & 97.87 & 1.10 & 0.90 & 0.35 & 0.25 & 0.38
\end{tabular}

rate $=147 \mathrm{lmin}^{-1}$, feeding rate $=20 \mathrm{~g} / \mathrm{min}$, spraying distance $=250 \mathrm{~mm}$, traverse gun speed $=500 \mathrm{~mm} / \mathrm{s}$ and number of layers $=9$. In addition, the samples were cooled with compressed air during the spraying process. Nitrogen was used as the powder carrying and shielding gas.

Hot corrosion studies were conducted in molten salt $\left(\mathrm{Na}_{2} \mathrm{SO}_{4}\right)$ at $850{ }^{\circ} \mathrm{C}$ for all specimens $(\operatorname{Ref} 80,81)$ with dimensions of $35 \times 20 \times 5 \mathrm{~mm}$. The samples were cut using the wire electric discharge machining technique, following the $\mathrm{HVOF}$ spraying. The $\mathrm{Na}_{2} \mathrm{SO}_{4}$ tablet $(0.2 \mathrm{~g}$ pulp and $5 \mathrm{~mm}$ in diameter) was pressed under $0.4 \mathrm{MPa}$ and placed on the surfaces of the coatings. First, the samples were mounted in a furnace preheated to $950{ }^{\circ} \mathrm{C}$ and annealed for $10 \mathrm{~min}$ in an oven to melt $\mathrm{Na}_{2} \mathrm{SO}_{4}$. (Melting point of the salt is close to $890{ }^{\circ} \mathrm{C}$.) Then, the temperature was lowered to $850{ }^{\circ} \mathrm{C}$ and the samples were saturated successively for $45 \mathrm{~h}$ in order to evaluate the coatings behavior under hot corrosion conditions in the aggressive environment.

The microstructural characteristics of the feedstock powder, as well as initial and corroded coatings, were obtained by SEM/EDS using the Quanta 3D FEG Dual Beam and JEOL 5310 microscopes operating at $20 \mathrm{kV}$. The backscattered images were obtained with a K.E. developments detector. Coating porosity was evaluated by means of the image analysis ImageJ software. Qualitative microanalysis was performed by EDS with a RÖNTEC detector. Additionally, the roughness of the coatings was measured by confocal microscopy (Leica DCM3D).

XRD was used to characterize the phases and assess the degree of order in the feedstock powders and sprayed coatings. All x-ray measurements were carried out with the Bragg-Brentano $\theta / 2 \theta$ Siemens D-500 diffractometer with $\mathrm{Cu} \mathrm{K} \alpha$ radiation.

\section{Results and Discussion}

\section{Feedstock Powder}

Figure 1 shows the particle size distribution of the powders. It can be observed that the ball-milled powder 1 is characterized by the Gaussian distribution centered at a mean size of $30 \mu \mathrm{m}$, while powder 2 shows a non-symmetric distribution with $d 10=3 \mu \mathrm{m} / d 90=56 \mu \mathrm{m}$. The self-decomposed powder 3 contains a large amount of fine particles with $d 10=3 \mu \mathrm{m} / d 90=60 \mu \mathrm{m}$, while $d 10=7 \mu \mathrm{m} / d 90=68 \mu \mathrm{m}$ was recorded in powder 4 .

The SEM-BSE micrographs of the cross sections show that all the powder particles exhibit irregular morphology and reveal uniform composition of powder 1 , whereas the rest presents a varying degree of grayness (Fig. 2). Their compositions are presented in Table 3 for different EDX point microanalysis. Powder 2 contains a varying chemical composition with diversified content of $\mathrm{Al}, \mathrm{Cr}$ and $\mathrm{Ti}$ in individual particles, as well as separate regions of $\mathrm{Al}_{2} \mathrm{O}_{3}$ (Fig. 2b). Self-decomposed powder 3 shows regions identified as $\mathrm{SiO}_{2}$ and predominant light gray areas with aluminum content significantly higher than iron (Fig. 2c). In powder 4 , the distribution of the phases from one particle to the other is quite different (Fig. 2d), with some particles exhibiting a mixed laminar structure of two phases. Thus, it was determined that the SHS intermetallic powder showed a wide range of chemical compositions of the Fe-Al-based phases in single powder particles (52-73 at.\%), which suggests that they were secondary solutions based on $\mathrm{Fe}-\mathrm{Al}$ phases with wide range of $\mathrm{Al}$ content and trace amounts of Cr.

Figure 3 shows the XRD results of the powders. Powder 1 presents typical fundamental lines of the $\mathrm{FeAl}$ pattern $(h+k+l=$ even), exhibited only when the structure is disordered, as otherwise, the superlattice lines $(h+k+$ 1 = odd) would also appear. The occurrence of broad peaks is related to the fine grain size and microstrains resulting from the milling.

Based on Senderowski's results (Ref 57), the low-energy milling of the powder particles causes crystallite fragmentation, resulting in the formation of the nanocrystalline structure of the powder particles. Low-energy 


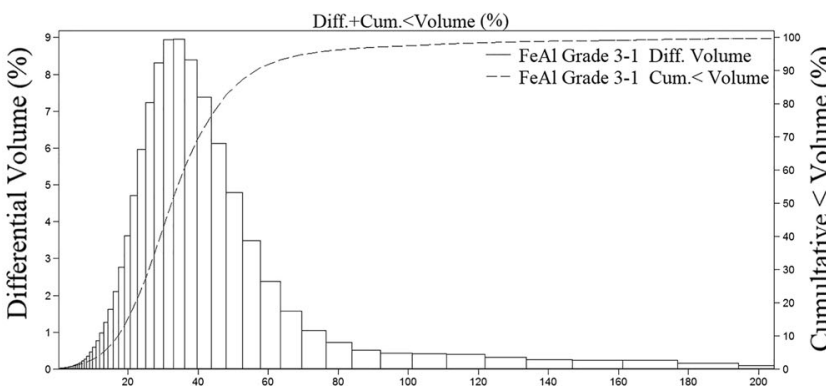

(a)

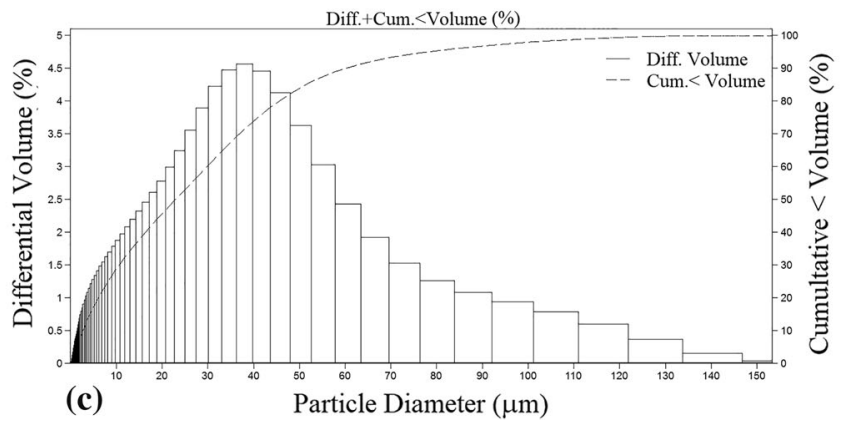

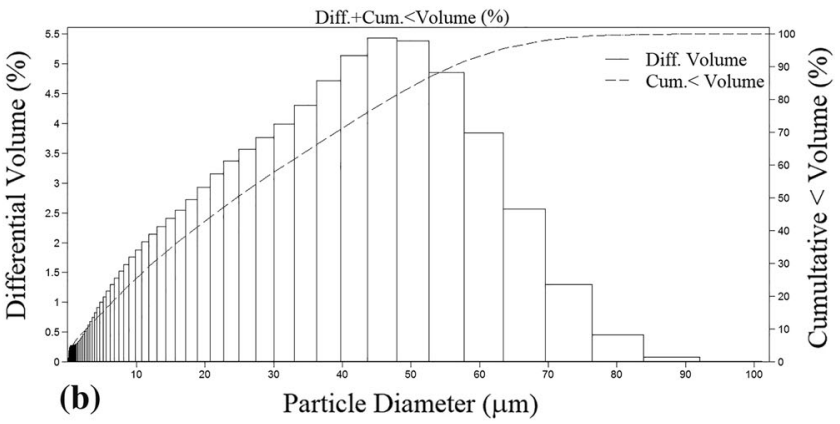

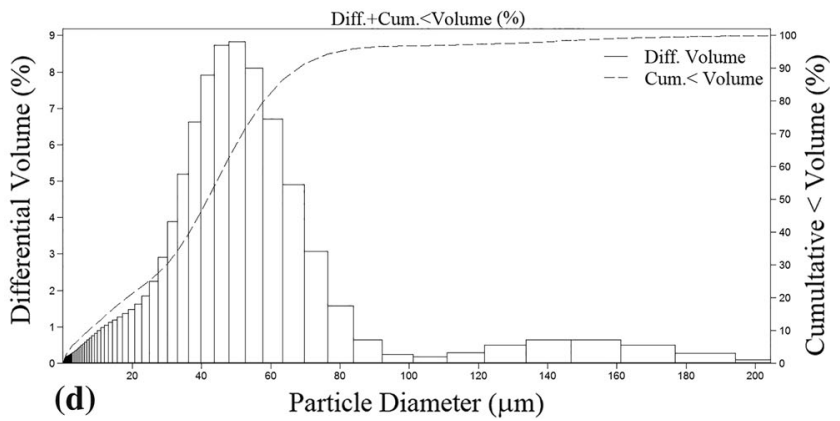

Fig. 1 Particle size distribution of: (a) powder 1, (b) powder 2, (c) powder 3, (d) powder 4

Fig. 2 SEM images in the cross sections of: (a) powder 1 and, (b) powder 2, (c) powder 3, (d) powder 4
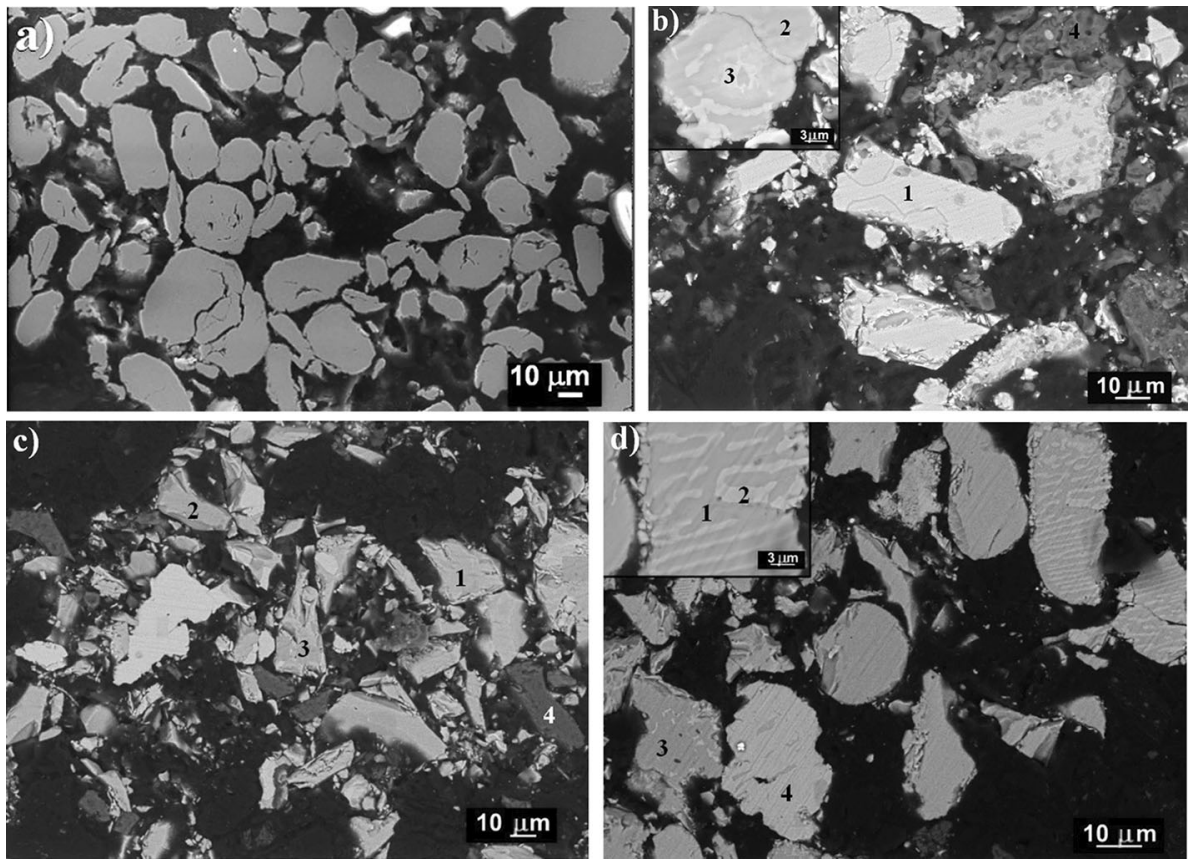

milling decreases the ordering degree of the FeAl secondary solution, which in turn limits the strength of the particles. Nevertheless, this is compensated with strengthening, which originates from the crystallite fragmentation.

Powder 2 contains Fe-Al and Ti-Al intermetallics, while the XRD of powder 3 confirms the presence of different intermetallic $\mathrm{Fe}-\mathrm{Al}$ phases, mainly $\mathrm{Fe}_{2} \mathrm{Al}_{5}$ and $\mathrm{FeAl}_{3}$, together with trace amounts of $\mathrm{SiO}_{2}$. Silicon embrittles the material. A clear explanation and concise description of the self-decomposing process are presented in Ref 56, 57, where it was reported that many hypothesis can be introduced to explain the self-decomposition of the Pyroferal cast-iron casts.

The Pyroferal casts structure, which depends on the chemical composition, is made of the following intermetallic phases: $\mathrm{Fe}_{3} \mathrm{Al}$ and $\mathrm{FeAl}$, or $\mathrm{FeAl}$ and $\mathrm{Al}_{4} \mathrm{C}_{3}$ 
Table 3 Semiquantitative EDS analysis (at.\%) of different FeAl-type powders used for HVOF spraying

\begin{tabular}{lllllll}
\hline Designation of grain area according to Fig. 2 & \multicolumn{5}{c}{ Content, at.\% } \\
\cline { 2 - 7 } & $\mathrm{Al}$ & $\mathrm{Ti}$ & $\mathrm{Cr}$ & $\mathrm{Fe}$ & $\mathrm{Si}$ & $\mathrm{O}$ \\
\hline Powder 2-Fig. 3(b) & & & & & & \\
1-Light & 37.8 & 11.3 & 11.0 & 39.8 & $\ldots$ & $\ldots$ \\
2-Dark gray & 63.7 & 26.3 & 3.1 & 6.9 & $\ldots$ & $\ldots$ \\
3-Light gray & 48.9 & 21.5 & 4.5 & 25.1 & $\ldots$ & $\ldots$ \\
4-Dark & 33.5 & $\ldots$ & $\ldots$ & $\ldots$ & $\ldots$ & 66.5 \\
Powder 3-Fig. 3(c) & & & & & & \\
1-Light gray & 67.7 & $\ldots$ & $\ldots$ & 27.1 & 5.2 & $\ldots$ \\
2-Dark gray & 36.9 & $\ldots$ & $\ldots$ & 18.5 & 16.0 & 28.5 \\
3-Medium gray & 61.6 & $\ldots$ & $\ldots$ & 25.0 & 2.8 & 10.5 \\
4-Dark & $\ldots$ & $\ldots$ & $\ldots$ & 0.5 & 31.1 & 68.4 \\
Powder 4-Fig. 3(d) & & & & & & \\
1-Dark gray & 65.3 & $\ldots$ & $\ldots$ & 34.7 & $\ldots$ & $\ldots$ \\
2-Light gray & 52.5 & $\ldots$ & $\ldots$ & 47.5 & $\ldots$ & $\ldots$ \\
3-Dark gray & 72.5 & $\ldots$ & $\ldots$ & 27.5 & $\ldots$ & $\ldots$ \\
4-Light gray & 52.1 & $\ldots$ & 2.1 & 44.4 & 1.4 & $\ldots$ \\
\hline
\end{tabular}

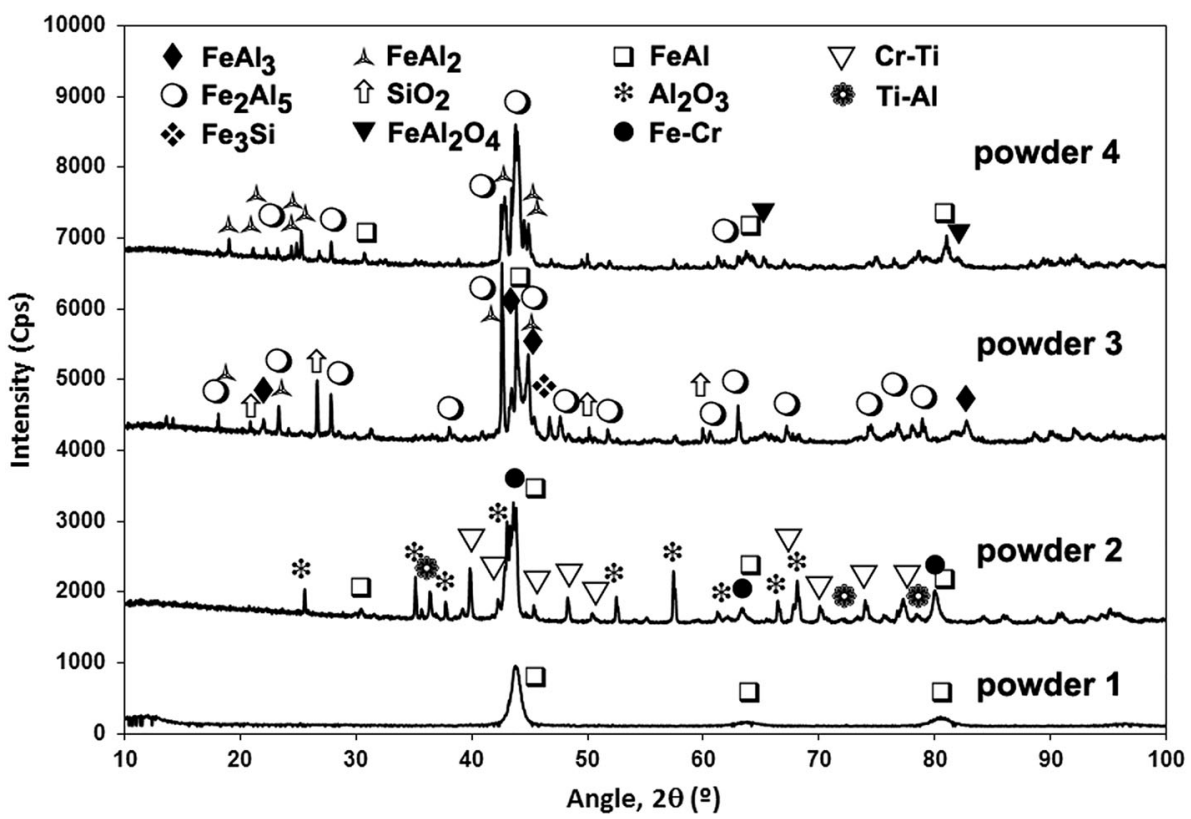

Fig. 3 XRD diffraction patterns of the feedstock powders at the initial state (from the manufacturer) aluminum carbide, trace amounts of graphite. The most common hypothesis of the self-decomposition suggests that secretions of aluminum carbide $\mathrm{Al}_{4} \mathrm{C}_{3}$ react with water vapor on the surface of the Fe-Al-C-Me alloys $(\mathrm{Me}=\mathrm{Ni}$, $\mathrm{Mn}, \mathrm{Cr}, \mathrm{Mo}, \mathrm{V}, \mathrm{B}, \mathrm{Si}$ ) and create aluminum hydroxide and methane (Ref 57):

$$
\mathrm{Al}_{4} \mathrm{C}_{3}+12 \mathrm{H}_{2} \mathrm{O} \rightarrow 4 \mathrm{Al}(\mathrm{OH})_{3}+3 \mathrm{CH}_{4} \uparrow
$$

The cracking and fragmenting of the castings occur under the influence of stresses caused by the product $\mathrm{Al}(\mathrm{OH})_{3}$, characterized by a higher specific volume than reacting $\mathrm{Al}_{4} \mathrm{C}_{3}$ carbide.
Powder 4 consists of strongly oxidized secondary solution on the $\mathrm{FeAl}$ intermetallic base with a widely varying content of aluminum and thin $\mathrm{Al}_{2} \mathrm{O}_{3}$ films covering the particle surface, which has a bearing on their growing importance in the production of coatings with a nanocomposite structure.

The strong diversification of chemical composition between single particles as well as within the area inside shows that the tested powder has the structure of a secondary solution based on phases from the Fe-Al equilibrium phase diagram, with a wide span of changes in $\mathrm{Al}$ and sparse distribution of $\mathrm{Cr}$ and $\mathrm{Si}$. It is to be assumed that the 
Fig. 4 SEM images in cross section of the as-sprayed $\mathrm{HVOF}$ coatings obtained with:

(a) powder 1 -coating 1 ,

(b) powder 2-coating 2 ,

(c) powder 3-coating 3, and

(d) powder 4-coating 4
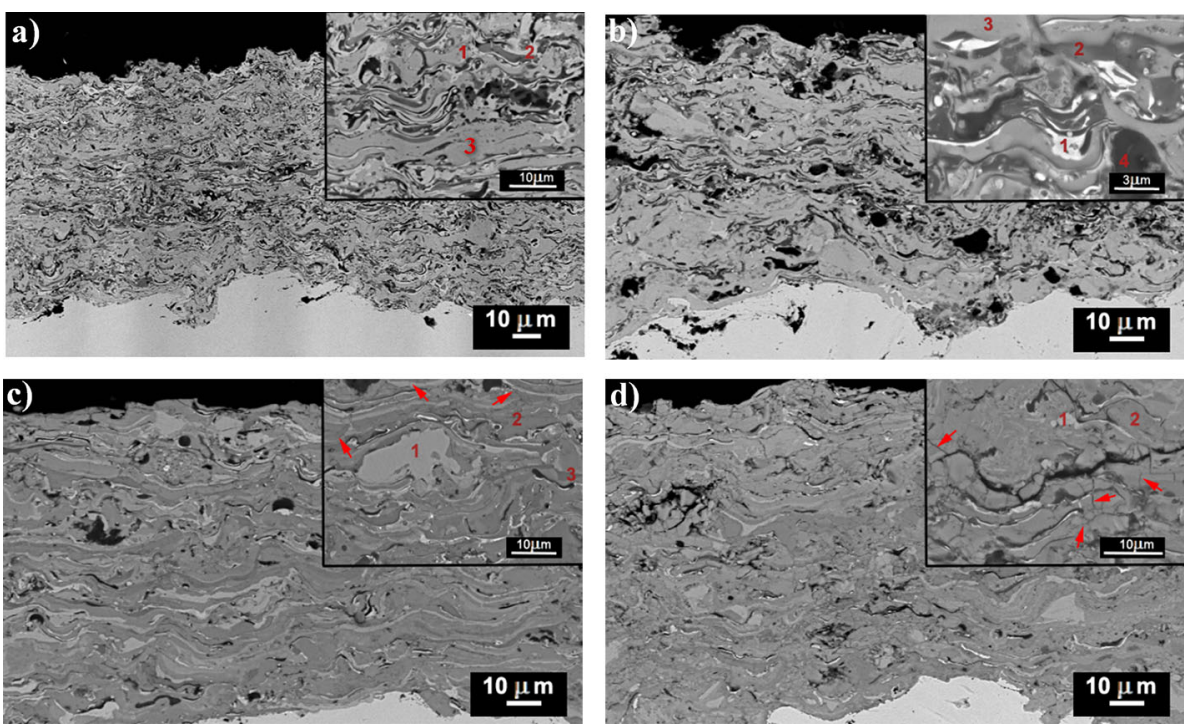

formation of oxide films on the surface of the powder particles is most likely attributable to self-propagating high-temperature synthesis, a phenomenon strongly exothermic in its nature. The oxide formation may as well be related to the technological process consisting of crashing and high-energy mechanical milling during selective heat sintering onto a powder.

In consequence, the XRD analysis of powder 4 revealed the formation of $\mathrm{FeAl}, \mathrm{FeAl}_{2}, \mathrm{Fe}_{2} \mathrm{Al}_{5}$ and $\mathrm{FeAl}_{2} \mathrm{O}_{4}$ phases under the SHS process. Relatively high half-width of the overlapping reflections of $\mathrm{Fe}-\mathrm{Al}$ phases is the result of a wide span of $\mathrm{Al}$ content across the area containing individual powder particles (Fig. 3), which leads to a network deformation within each phase and generation of residual stress. Moreover, the latter is amplified by crushing and high-energy mechanical milling of sinters following the SHS process.

\section{As-Sprayed Coating Microstructures}

Figure 4 shows the cross sections of as-sprayed HVOF coatings with thickness of $103 \pm 9 ; 84 \pm 10 ; 76 \pm 13$;
Table 4 Semiquantitative EDS analysis (at.\%) of as-HVOFsprayed $\mathrm{Fe}-\mathrm{Al}$ coatings from different types of powders (presented in Tab. 2)

\begin{tabular}{|c|c|c|c|c|c|c|c|}
\hline \multirow[t]{2}{*}{ Designation of grain area according to Fig. 4} & \multicolumn{6}{|c|}{ Content, at. $\%$} & \multirow[b]{2}{*}{$\mathrm{Y}$} \\
\hline & $\mathrm{Al}$ & $\mathrm{Ti}$ & $\mathrm{Cr}$ & $\mathrm{Fe}$ & $\mathrm{Si}$ & $\mathrm{O}$ & \\
\hline \multicolumn{8}{|l|}{ Coating 1-Fig. 5(a) } \\
\hline 1-Light gray & 28.2 & $\cdots$ & $\ldots$ & 71.6 & $\ldots$ & $\ldots$ & 0.2 \\
\hline 2-Medium gray & 33.3 & $\cdots$ & $\ldots$ & 66.2 & $\ldots$ & $\ldots$ & 0.5 \\
\hline 3-Dark gray & 31.6 & $\cdots$ & $\ldots$ & 52.2 & $\ldots$ & 15.8 & 0.4 \\
\hline \multicolumn{8}{|l|}{ Coating 2-Fig. 5(b) } \\
\hline 1-Light & 3.8 & 6.2 & 11.9 & 69.5 & $\cdots$ & 7.4 & $\cdots$ \\
\hline 2-Dark gray & 16.1 & 11.5 & 3.3 & 15.7 & $\ldots$ & 53.4 & $\ldots$ \\
\hline 3-Light gray & 38.5 & 23.0 & 5.8 & 32.7 & $\ldots$ & $\ldots$ & $\ldots$ \\
\hline 4-Dark & 35.1 & $\sim 0.8$ & $\ldots$ & $\sim 0.6$ & $\ldots$ & 63.5 & $\ldots$ \\
\hline \multicolumn{8}{|l|}{ Coating 3-Fig. 5(c) } \\
\hline 1-Light gray & 41.4 & $\cdots$ & $\ldots$ & 45.0 & 13.6 & $\cdots$ & $\cdots$ \\
\hline 2-Medium gray & 57.4 & $\cdots$ & $\ldots$ & 26.6 & 6.9 & $\sim 9.0$ & $\cdots$ \\
\hline 3-Dark gray & 63.0 & $\ldots$ & $\ldots$ & 19.7 & 10.4 & 6.9 & $\ldots$ \\
\hline \multicolumn{8}{|l|}{ Coating 4-Fig. 5(d) } \\
\hline 1-Light gray & 40.6 & $\cdots$ & 2.5 & 55.5 & 1.4 & $\cdots$ & $\cdots$ \\
\hline 2-Medium gray & 68.1 & $\ldots$ & 0.9 & 31.0 & $\ldots$ & $\ldots$ & $\ldots$ \\
\hline
\end{tabular}


and $93 \pm 11 \mu \mathrm{m}$, obtained through spraying nine layers, for each one of the four powders presented in Table 1. The coating obtained with the pre-alloyed powder (powder 1) is quite uniform in thickness, whereas other are less homogeneous; the values of roughness were found to be $\mathrm{Ra}=$ $3.6 \pm 0.6 ; \quad 5.1 \pm 0.7 ; \quad 4.3 \pm 0.3 ; \quad$ and $\quad 6.8 \pm 0.4 \mu \mathrm{m}$, respectively. The highest porosity of $1.45 \pm 0.02 \%$ corresponds to coating 4 (as-sprayed powder 4 , from now on label coating $\mathrm{X}$ stands for as-sprayed powder $\mathrm{X}$ ).

The examination of the microstructure indicates that the uniform distribution of the oxidation occurs in-flight rather than after the splat impact.

The powder particles are usually melted or at least premelted, as a result of HVOF spraying, during which the gas mixture is being continuously combusted under high pressure (Ref 28, 33-35, 39-43, 46). As a result of the thermal activation of gaseous products in the HVOF process, the in situ formation of thin and complex oxide films on the internal splat interfaces is affected. The oxide films, identified mainly as $\mathrm{Al}_{2} \mathrm{O}_{3}$ compounds, become a specific composite reinforcement in a $\mathrm{Fe}-\mathrm{Al}$ intermetallic coating (Ref 33, 34, 40-43, 45, 46). Oxides are formed during the HVOF process in the phase during which the gaseous products transport the powder particles, along with rapid chemical reactions, accompanied by the release of a great amount of thermal energy (Ref 40-43).

The presence of a lamellar structure resulting from partly melted and oxidized particles with inhomogeneous compositions (Table 4) and intersplat porosity can be observed at higher magnification (Fig. 4). The nature of coating 1 is well documented by partially and fully melted particles exhibiting different degrees of grayness at the boundaries of the intersplats (Fig. 4a). The light areas in
Fig. 6 Typical lamellar-like microstructure in the cross sections of the as-sprayed HVOF coating and, after molten salt corrosionobtained with powder $1(\mathrm{a}, \mathrm{b})$ and SEM/EDX results with corresponding EDX maps of $\mathrm{Fe}$ (c), $\mathrm{Al}$ (d), $\mathrm{O}$ (e), $\mathrm{Na}$ (f) and $\mathrm{S}$ (g) distributions

the intersplats correspond to the Al-depleted regions, whereas the darkest ones are attributed to spinel oxides (Ref 56).

Furthermore, the XRD results confirm the findings (Fig. 5); the additional peaks, also identified as $\mathrm{FeAl}$, correspond to the superlattice lines due to ordering of the intermetallic phase as a result of the thermal history of particles in the flame. Light regions around the intersplat boundaries of coating 2 in Fig. 4(b) are poorer in $\mathrm{Al}$ and $\mathrm{Ti}$, which in fact are located next to the dark gray areas identified as oxides (Fig. 5). Coating 2 is reinforced by the incorporation of alumina, visible as intensely dark areas in the shape of circle-like figures. The $\mathrm{SiO}_{2}$ particles act as some sort of reinforcement in coating 3 (dark regions in Fig. 4c). The light gray regions in coating 3 correspond to iron-rich phases, while the darker predominant contrast reveals more balanced iron and aluminum content (Fig. 4c). Some porosity is observed; however, the extend of oxidation is significantly lower in relation to coating 1 . $\mathrm{SiO}_{2}$ particles from the feedstock can be found as very dark regions, uniformly distributed within the coating. In coating 4 , the lightest regions are poorer in aluminum than the medium gray ones and are identified as $\mathrm{Fe}_{3} \mathrm{Al}$ phase, whereas the medium gray contrast is mainly identified as $\mathrm{FeAl}_{2}$ and $\mathrm{Fe}_{2} \mathrm{Al}_{5}$ (Fig. 4d).
Fig. 5 XRD diffraction patterns of the as-sprayed HVOF coatings (according to the legend)

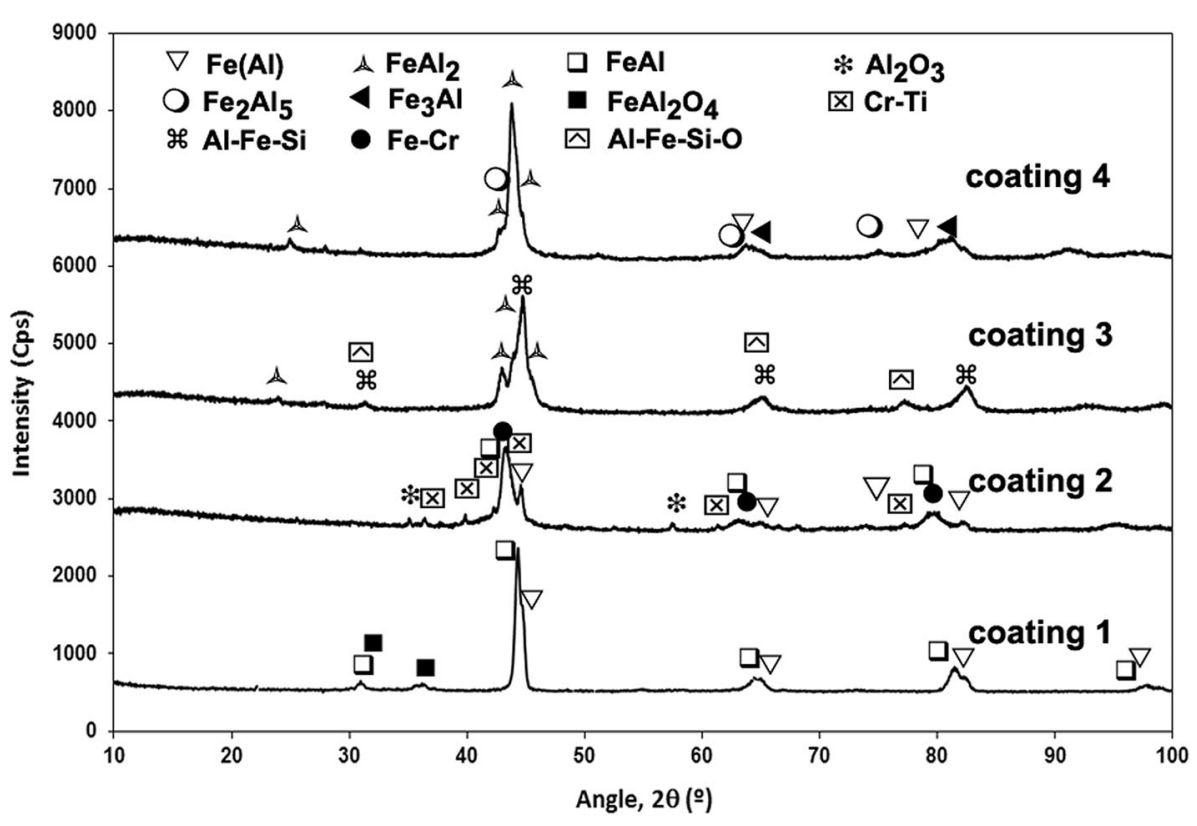



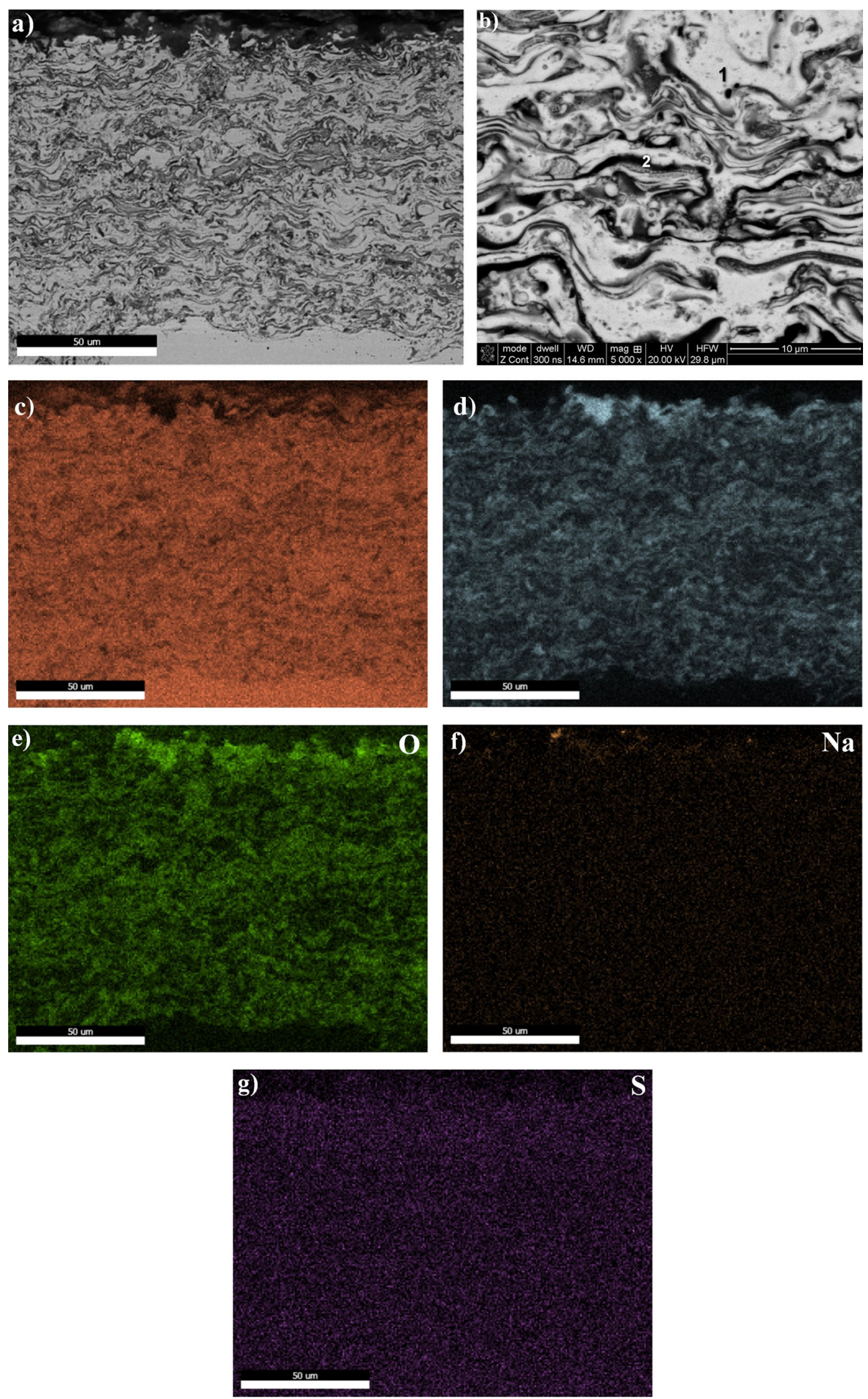
Table 5 Semiquantitative EDS analysis (at.\%) of the HVOFsprayed $\mathrm{Fe}-\mathrm{Al}$ coatings after the molten salt corrosion

\begin{tabular}{lccccccc}
\hline Designation of grain area & \multicolumn{7}{c}{ Content [at.\%] } \\
\cline { 2 - 6 } & $\mathrm{Al}$ & $\mathrm{Ti}$ & $\mathrm{Cr}$ & $\mathrm{Fe}$ & $\mathrm{Si}$ & $\mathrm{O}$ & $\mathrm{Na}$ \\
\hline Coating 1-Fig. 7(b) & & & & & & \\
1-Light & 20.4 & $\ldots$ & $\ldots$ & 70.2 & $\ldots$ & $\sim 9$ & $\ldots$ \\
2-Dark & 39.9 & $\ldots$ & $\ldots$ & 21.1 & $\ldots$ & $\sim 39$ & 0.1 \\
Coating 2-Fig. 8(b) & & & & & & & \\
1-Dark & 49.4 & 1.9 & 0.2 & 1 & $\ldots$ & $\leq 48$ & $\ldots$ \\
2-Light gray & 23.3 & 35.6 & 3.0 & 19.4 & $\ldots$ & $\sim 19$ & $\ldots$ \\
3-Light & 34.6 & 11.9 & 7.9 & 29.2 & $\ldots$ & $\leq 16$ & $\ldots$ \\
4, 5-Dark gray & 34.4 & 13.9 & 4.0 & 11.2 & $\ldots$ & $\leq 36$ & $\ldots$ \\
Coating 3-Fig. 9(b) & & & & & & & \\
1-Light gray & 39.6 & $\ldots$ & $\ldots$ & 42.2 & $\ldots$ & $\sim 18$ & $\ldots$ \\
2-Dark gray & 47.6 & $\ldots$ & $\ldots$ & 14.7 & 3.2 & $\sim 34$ & $\ldots$ \\
Coating 4-Fig. 10(a) and (b) & & & & & & & \\
Area 1 & 41.7 & $\sim 0.3$ & 1.5 & 27.3 & $\sim 0.4$ & $\sim 28$ & $\sim 0.2$ \\
Area 2 & 31.2 & $\ldots$ & $\sim 0.6$ & 56 & $\sim 0.4$ & $\sim 11$ & $\ldots$ \\
1-Light & 47.8 & $\sim 0.4$ & 1.3 & 11.7 & $\sim 0.1$ & $\sim 38$ & $\sim 0.5$ \\
2-Dark & 24.7 & $\sim 0.2$ & 17.3 & 50.4 & 0.9 & $\sim 6$ & $\sim 0.1$ \\
\hline
\end{tabular}

The degree of melting or semi-melting of the particles in HVOF within the coating can be controlled by process variables, i.e., fuel and oxygen flow rates, spraying distance and particle size. The process variables determine particle temperature and velocity upon impact and, thus, the typical lamellar structure of thermal-sprayed coatings. Many different iron aluminide compositions have been deposited using these technologies (Ref 17, 27, 28, 33-47, 82). However, different distributions of the intermetallic phases and Fe-rich areas are usually observed after the evaluation of their structural characterization. Moreover, these areas are aluminum-depleted as a result of the thermal history of the particles in the flame.

Low oxygen-to-fuel ratio is normally preferred in order to minimize oxidation, whereas lower carrying gas flow implies slower particle velocities; a higher in-flight period promotes further oxidation (Ref 43,70 ). The formation of intersplat oxides, and thus the occurrence of Al-depleted regions, may stimulate corrosion in field performance; at the same time, such oxides may also increase coating hardness and wear resistance. For example, Totemeier et al. 70 observed a decrease in the oxide content and coating porosity both in $\mathrm{Fe}_{3} \mathrm{Al}$ and in $\mathrm{FeAl}$ cases when the chamber pressure was increased, because it directly affects particle velocity and thus their degree of melting. However, the particle temperature for $\mathrm{FeAl}$ was lower than for the $\mathrm{Fe}_{3} \mathrm{Al}$ powder, probably because of the lesser thermal conductivity of $\mathrm{FeAl}$. Considering those factors, $\mathrm{Al}_{2} \mathrm{O}_{3}$ can clearly act as a reinforcement phase in coating 2, aiding $\mathrm{Al}$ and $\mathrm{Cr}$ oxidation which leads to forming a protective layer. On the whole, it is important to point out that the resulting $\mathrm{Al}$ content and distribution in the as-sprayed coating also determine corrosion properties.

Some microcracks, formed perpendicularly to the layer, were observed particularly in coating 4 and less noticeably in coating 3; such microcracks are attributed to the brittleness of the intermetallic phases, which are unable to withstand the deformation upon impact at high particle velocities. The grain boundaries were not the most common areas favoring the propagation of cracks, and therefore good cohesive strength is assumed. The microcrack network for the as-sprayed SHS powder (coating 4, see arrows in inset Fig. 4d) does not exhibit a specific direction within individual splats, which confirms the correspondence between embrittlement and the occurrence of Al-rich phases, namely $\mathrm{Fe}_{2} \mathrm{Al}_{5}$ and $\mathrm{FeAl}_{2}$.

For the as-sprayed self-decomposed powder (coating 3, see arrows in inset Fig. 4c), the microcracks are perpendicular to the coating surface, which suggests that the cracking is also due to the influence of tensile thermal strain sustained during rapid quenching of splats. The values of the linear thermal expansion coefficient for $\mathrm{Fe}$ Al-type intermetallic phases (ranging from $15 \times 10^{-6}$ up to $22 \times 10^{-6} \mathrm{~K}^{-1}$ ) are significantly different in comparison with these of the steel substrate $\left(12 \times 10^{-6} \mathrm{~K}^{-1}\right)$ (Ref $58,59)$. Some of the cracks found in the ball-milled $\mathrm{Cr}$ - and Ti-alloyed powder (coating 2, see arrows in inset Fig. 4b) may be additionally linked to the impact of the hot metallic particles entering cooler $\mathrm{Al}_{2} \mathrm{O}_{3}$ regions.

Additionally, it was previously observed for $\mathrm{Fe} 40 \mathrm{Al}$ type coatings that equiaxed small grains were displayed in the unmelted areas, while columnar grains, typical for rapid 
Fig. 7 Typical lamellar-like microstructure in the cross sections of the as-sprayed HVOF coating and, after molten salt corrosion-obtained with powder $2(\mathrm{a}, \mathrm{b})$ and SEM/EDX results with corresponding EDX maps of $\mathrm{Fe}$ (c), $\mathrm{Al}$ (d), $\mathrm{Ti}$ (e), $\mathrm{Cr}$ (f), $\mathrm{O}(\mathrm{g}), \mathrm{Na}(\mathrm{h})$ and $\mathrm{S}$

(i) distributions
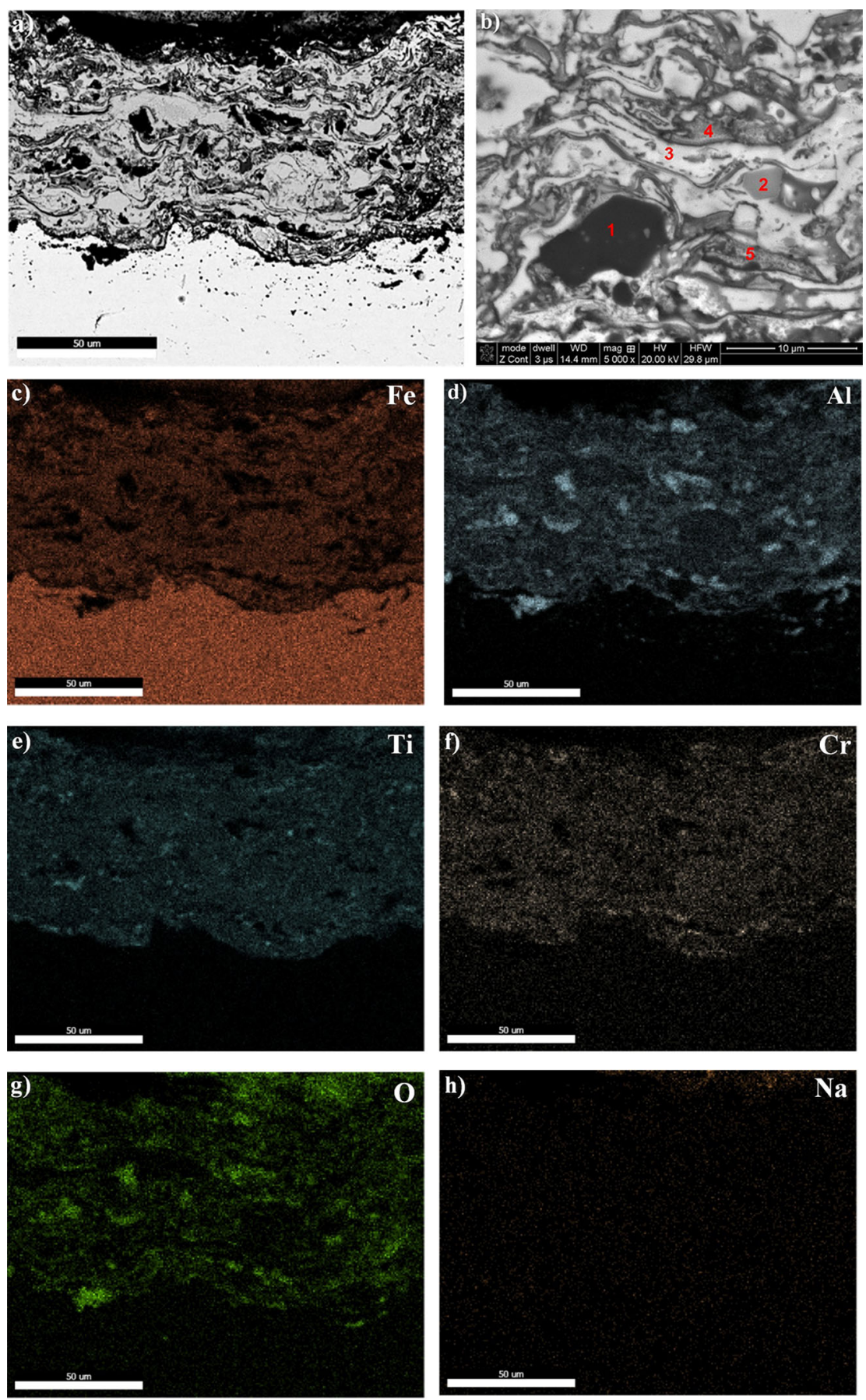

i)

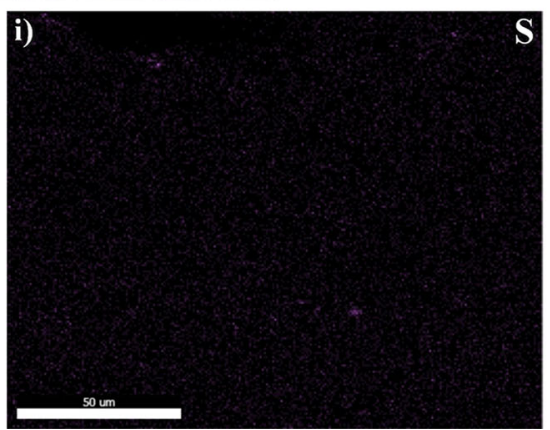



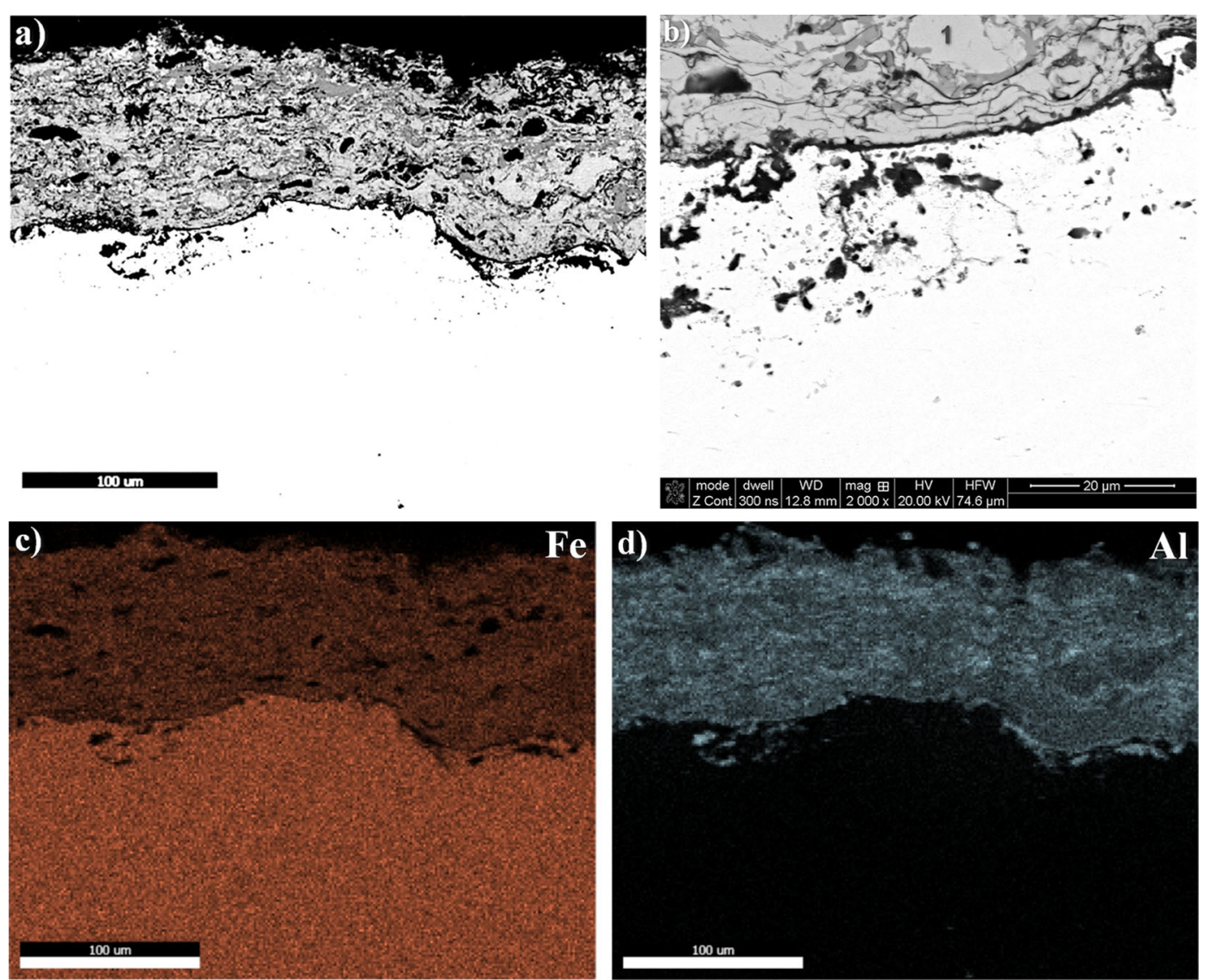

\section{Fig:}

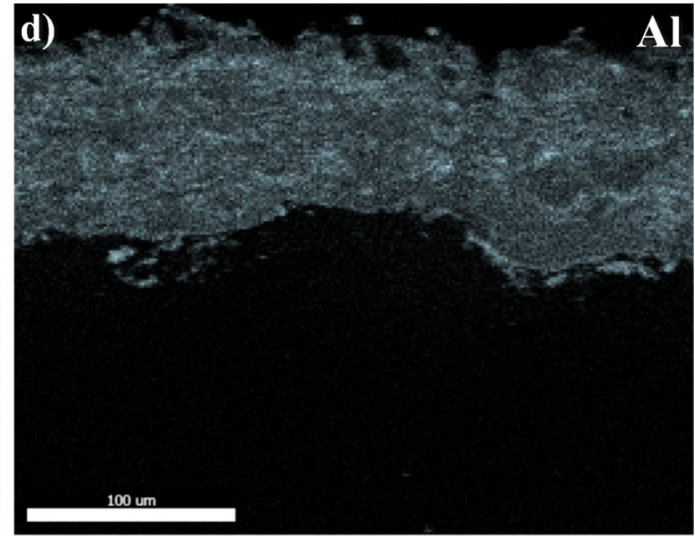

e)

0 f)
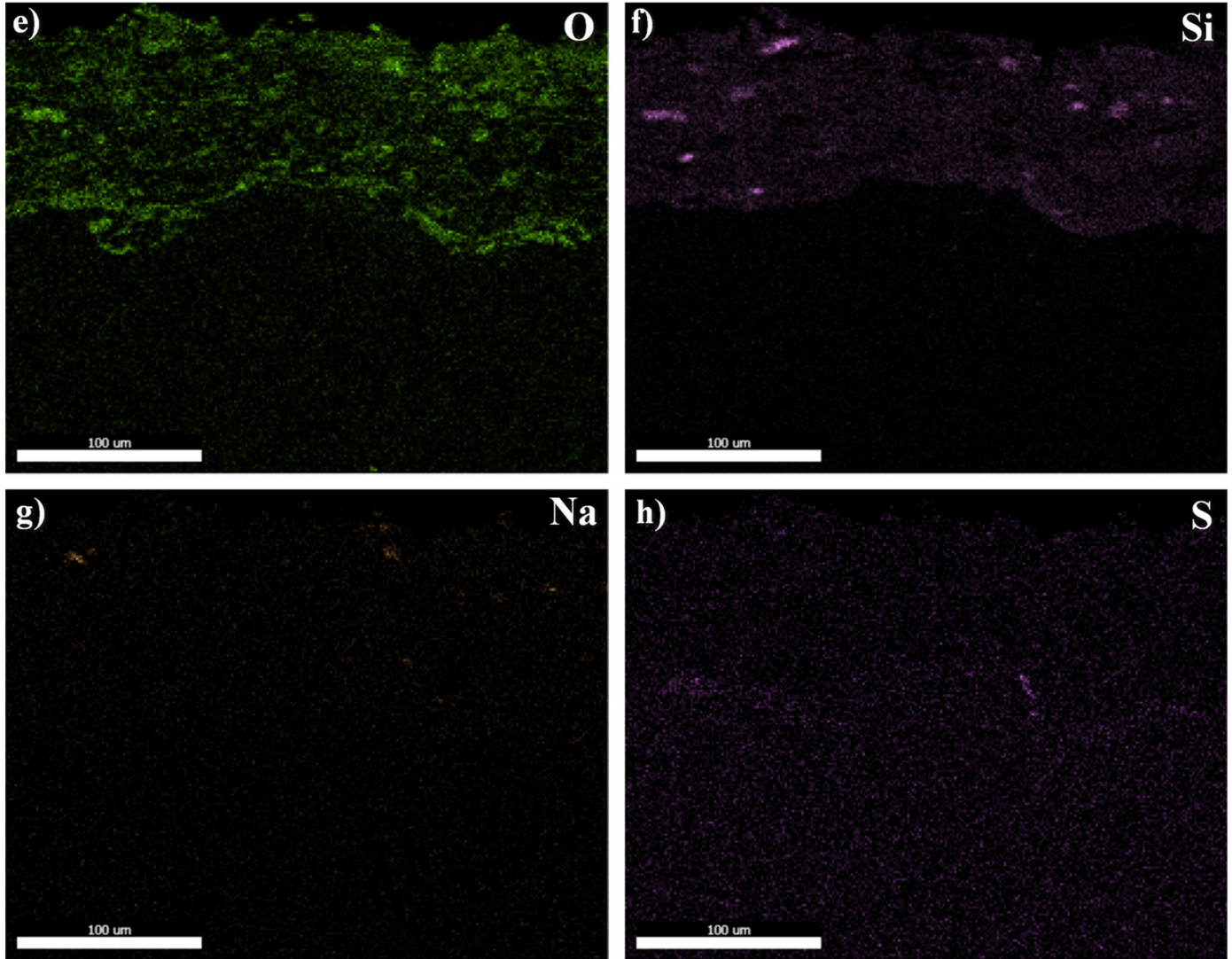

h) 
4Fig. 8 Typical lamellar-like microstructure in the cross sections of the as-sprayed HVOF coating and, after molten salt corrosionobtained with powder 3 (a, b) and SEM/EDX results with corresponding EDX maps of $\mathrm{Fe}$ (c), Al (d), O (e), Si (f), Na (g) and S (h) distributions

solidification processes, were visible in the melted regions. Interestingly, as a result of the thermal history of the milled particles in the flame, the final $\mathrm{FeAl}$ phase appears to be the ordered B2 lattice, present in the areas that reached the molten state (Ref 34,46$)$. Taking into consideration a higher melting point of the $\mathrm{FeAl}$ stoichiometric compound in relation to $\mathrm{Fe}_{2} \mathrm{Al}_{5}$ and $\mathrm{FeAl}_{2}\left(1250,1171\right.$ and $1157^{\circ} \mathrm{C}$, respectively), and the high particle heterogeneity of powders 3 and 4, there is a great likelihood that these phases melt during the formation of amorphous oxide (AO) (Ref 29, 46, 51-56). This results in the multi-phase (compositelike) structure of the $\mathrm{Fe}-\mathrm{Al}$ coatings ( $\operatorname{Ref} 29,56)$.

\section{Corrosion Performance}

Degradation and infiltration of $\mathrm{Na}$ and $\mathrm{S}$ elements within the coatings following exposure to $\mathrm{Na}_{2} \mathrm{SO}_{4}$ at $850{ }^{\circ} \mathrm{C}$ are examined in Fig. 6 to 9. The cross section of coating 1 (Fig. 6a, b) does not show significant damage compared to Fig. 4(a); the coating preserves its original thickness all along the tested sample. No infiltration of the salt can be observed within the splat boundaries (Fig. 6c-g). The light contrast (Fig. 6b) is poorer in aluminum than the assprayed state (spot 1-coating 1 Table 5), while the intersplat dark contrast is richer in oxygen.

A similar case is observed in the as-sprayed powders 2 (Fig. 7) and 3 (Fig. 8) where the oxygen diffusion is detected even within the splats. Following the tests, the non-oxidized phase in the as-sprayed coating 2 (spot 3 -coating 2 Table 4), which is nearly equal in $\mathrm{Fe}$ and $\mathrm{Al}$ content, becomes oxidized and enriched in chromium at the expense of depleted rate of titanium (spot 3-coating 2 Table 5). By contrast, the dark gray phase doubles its $\mathrm{Al}$ content while $\mathrm{O}$ content is reduced (spot 2-coating 2 Table 4 compared to spot 4 -coating 2 Table 5). The silicon in coating 3 appears to diffuse the core of the splats. Also, some oxide microareas are detected at the coating-substrate interface and have been identified as aluminum oxide (Fig. 8b). No significant amounts of sodium or sulfur were identified within the EDS maps (Fig. 7c-h, 8c-h).

Coating 4 suffered the highest damage as splat shapes are no longer visible and the deposit consists of a composite containing Al-rich oxide network with a Fe-rich matrix (Fig. 9a, b). Such a structure is visible to progress uniformly from the air-coating interface (area 1-coating 4 Table 5); it displays higher oxygen content than the rest of the coating (area 2-coating 4 Table 5). For that coating, regions near to the edges of the sample were severely damaged with considerable degradation observed; in these cases, $\mathrm{Na}$ and $\mathrm{S}$ concentrations escalated in proportion to visible infiltration.

Top surface oxide morphologies in Fig. 10 are contrasting with more granular shapes discovered in coatings 1,3 and 4, whereas coating 2 is more needle-shaped. Coating 1 was covered by iron oxide even when exposed to oxidation atmosphere (Ref 83 ). The needles in coating 2 were identified as mixed $\mathrm{Fe}$ and $\mathrm{Ti}$ oxides, with an oxide layer below, also rich in $\mathrm{Al}$ and $\mathrm{Cr}$ (Fig. 7). Coating 3 was mostly covered by alumina layer, while coating 4 was a mixed $\mathrm{Fe}$ and $\mathrm{Al}$ oxide; the scale fluxing may involve an interactive reaction between the basic dissolution of $\mathrm{Al}_{2} \mathrm{O}_{3}$ and the acidic dissolution of $\mathrm{Fe}_{2} \mathrm{O}_{3}$.

The XRD of the corroded coatings (Fig. 11a-d) shows that coating 1 is covered with two oxides, namely $\mathrm{Fe}_{2} \mathrm{O}_{3}$ and $\mathrm{Al}_{2} \mathrm{O}_{3}$. The results obtained from the EDS analysis (Fig. 6) confirm the depletion of $\mathrm{Al}$ in the $\mathrm{Fe}-\mathrm{Al}$ phase. The rapid growth of iron oxide was not observed in the rest of the coatings, yet alumina was identified; the aluminaidentified pattern phase is mainly $\alpha-\mathrm{Al}_{2} \mathrm{O}_{3}$ corundum; actually, it has been reported that the predominant surface product that forms between 600 and $800{ }^{\circ} \mathrm{C}$ is $\alpha-\mathrm{Al}_{2}$ -

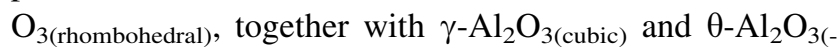
monoclinic) (Ref 84 ). The latter two phases are fast growing, more voluminous, more porous and less protective than $\alpha$ $\mathrm{Al}_{2} \mathrm{O}_{3}$; the heterogeneous growing of $\alpha-\mathrm{Al}_{2} \mathrm{O}_{3}$, also with some traces of $\gamma$ and $\theta$ phases, could also explain why the other coatings showed significant damage. According to the literature, the sequence is believed to be as follows: $\gamma$ $\mathrm{Al}_{2} \mathrm{O}_{3} \rightarrow \delta-\mathrm{Al}_{2} \mathrm{O}_{3} \quad\left(750{ }^{\circ} \mathrm{C}\right) ; \quad \delta-\mathrm{Al}_{2} \mathrm{O}_{3} \rightarrow \theta-\mathrm{Al}_{2} \mathrm{O}_{3}$ $\left(900{ }^{\circ} \mathrm{C}\right) ; \theta-\mathrm{Al}_{2} \mathrm{O}_{3} \rightarrow \alpha-\mathrm{Al}_{2} \mathrm{O}_{3}\left(1000{ }^{\circ} \mathrm{C}\right)$, and the precise temperature transformation from $\theta$ to $\alpha$ is influenced by the presence of reactive elements (Ref 85).

The formation of alumina consumes a certain quantity of $\mathrm{Al}$, reducing its activity and partial pressure of the oxygen. This caused a relative increase in the activities of the $\mathrm{Fe}$ and $\mathrm{S}$ and serves as a catalyst for the reaction with the molten mixture to obtain a compound such as FeS.

$$
\begin{aligned}
& 2 \mathrm{FeAl}+\mathrm{SO}_{3} \rightarrow \mathrm{Al}_{2} \mathrm{O}_{3}+\mathrm{S}+2 \mathrm{Fe} \\
& \mathrm{S}+\mathrm{Fe} \rightarrow \mathrm{FeS}
\end{aligned}
$$

Sulfur attack and penetration appear to be more visible in the edges of coating 4 (not presented here). Under the molten salt corrosion conditions, the dissolution of the component below can be produced by local dissolution or selective dissolution of different components of the oxide (Ref 86). Selective oxidation and dissolution of iron in coating 4 resulted in a loss of the coating integrity, leading to a high corrosion rate. In this case, sulfur may have moved from the oxide/molten salt interface toward the 

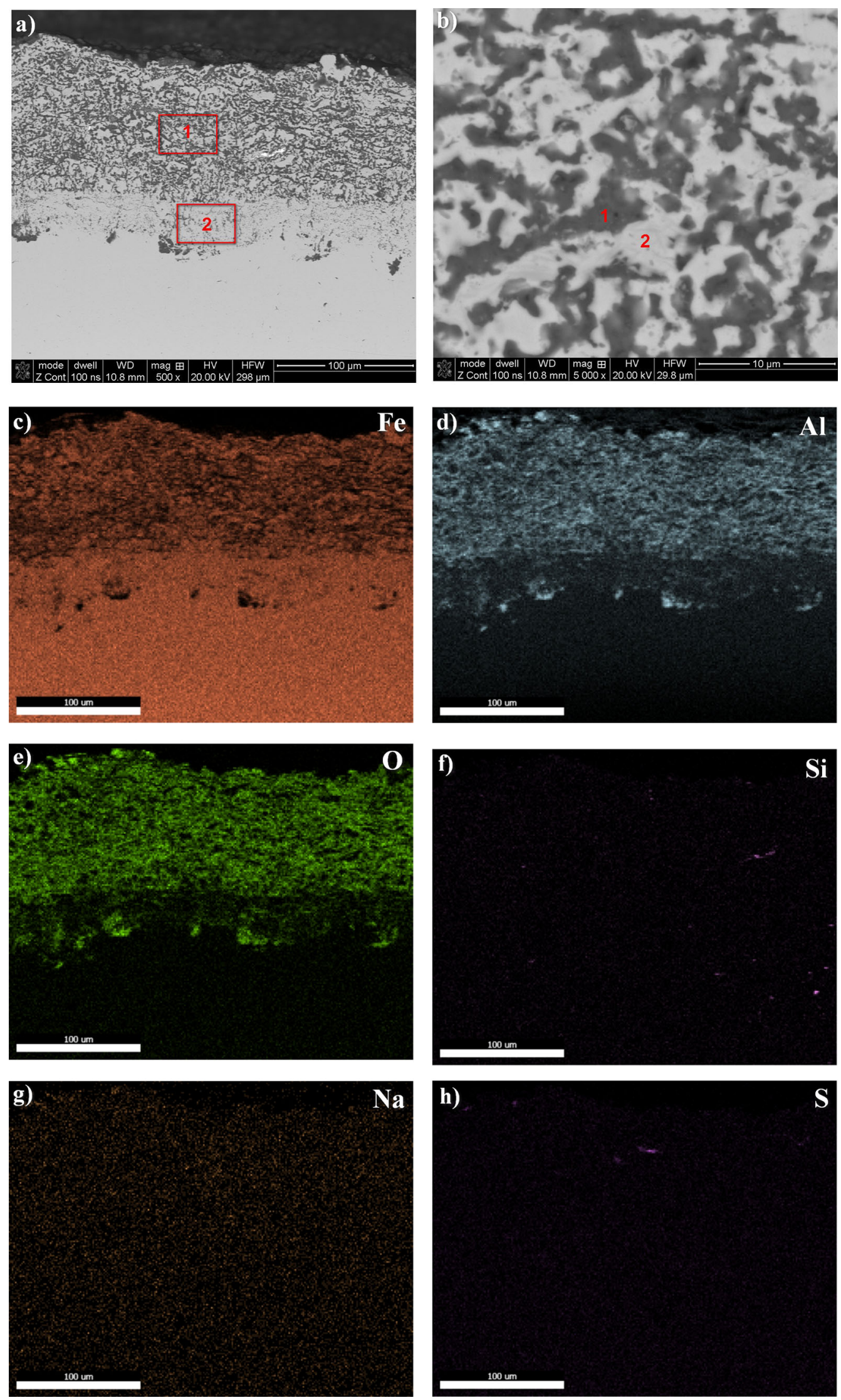
4Fig. 9 Typical lamellar-like microstructure in the cross sections of the as-sprayed HVOF coating and, after molten salt corrosionobtained with powder 4 (a, b) and SEM/EDX results with corresponding EDX maps of $\mathrm{Fe}$ (c), Al (d), O (e), Si (f), Na (g) and S (h) distributions

coating/substrate interface by diffusion or infiltration of the melt through the structural defects of the oxide scale. It proceeded through particle boundaries as well as microcrack networks until the moment it reached the steel substrate in some parts of the coating. It can be suspected that this local corrosion mechanism may have triggered the damage, causing metal dissolution in hot points. The decomposition of $\mathrm{Na}_{2} \mathrm{SO}_{4}$ would result in $\mathrm{SO}_{3}$ formation, which might have been the aggressive agent for the rapid preferential attack at coating defects (Ref 87). Sodium presence within the coating might follow the basic dissolution reaction at the oxide/molten salt interface: $\mathrm{Al}_{2} \mathrm{O}_{3}$ $+\mathrm{Na}_{2} \mathrm{O} \rightarrow 2 \mathrm{NaAlO}_{2}$ (Ref 19).

Corrosion in the rest of the coatings appears to have been produced by uniform oxidation at the coating/molten salt/air interface. The formation of the fast growing oxides indicates that the coating might be diluted upon longer exposure times, apparently without preference for any of the coating components. At $900{ }^{\circ} \mathrm{C}$, the $\mathrm{Fe} 40 \mathrm{Al}$ composition for bulk materials was found to be more resistant than Fe40Al-0.1B-10 $\mathrm{Al}_{2} \mathrm{O}_{3}$ (at.\%) (Ref 88). Apparently, a similar phenomenon applies to coating 2 , but the scale is much more complex, especially in contrast to coating 3 . Under the oxide scale, $\mathrm{Al}$ depletion was observed in the intermetallic phase. Less defective structure of the assprayed coatings and the favorable presence of other stoichiometric intermetallic phases may be the reason why their corrosion rates were lower than the ones observed in the as-sprayed SHS powder.

\section{Conclusion}

The results of experiments and subsequent analyses allowed an evaluation of hot corrosion performance of HVOF-sprayed coatings with $\mathrm{Fe}-\mathrm{Al}$ intermetallic matrix in molten $\mathrm{Na}_{2} \mathrm{SO}_{4}$ at $850{ }^{\circ} \mathrm{C}$ in an isothermal process in the span of $45 \mathrm{~h}$ under static conditions.

It was determined that under applied HVOF spraying conditions, Fe-Al powder particles form a stratified/laminar/pseudo-composite structure of the coating, in which the thickness varies in dependence of the $\mathrm{Fe}-\mathrm{Al}$ powder
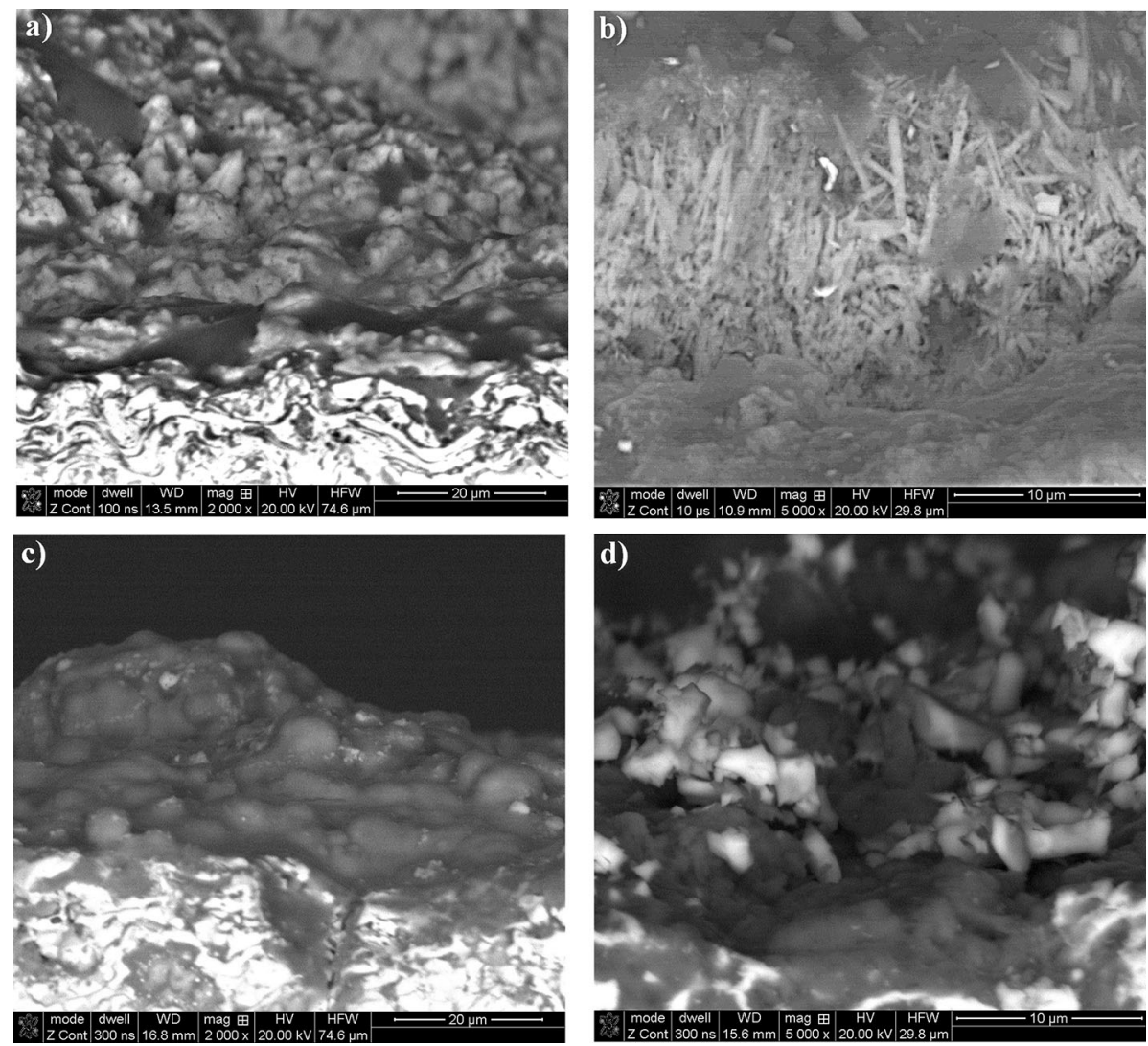

Fig. 10 SEM cross-section micrographs of the oxide layer on the coatings surface obtained from: (a) powder 1, (b) powder 2, (c) powder 3 and (d) powder 4 

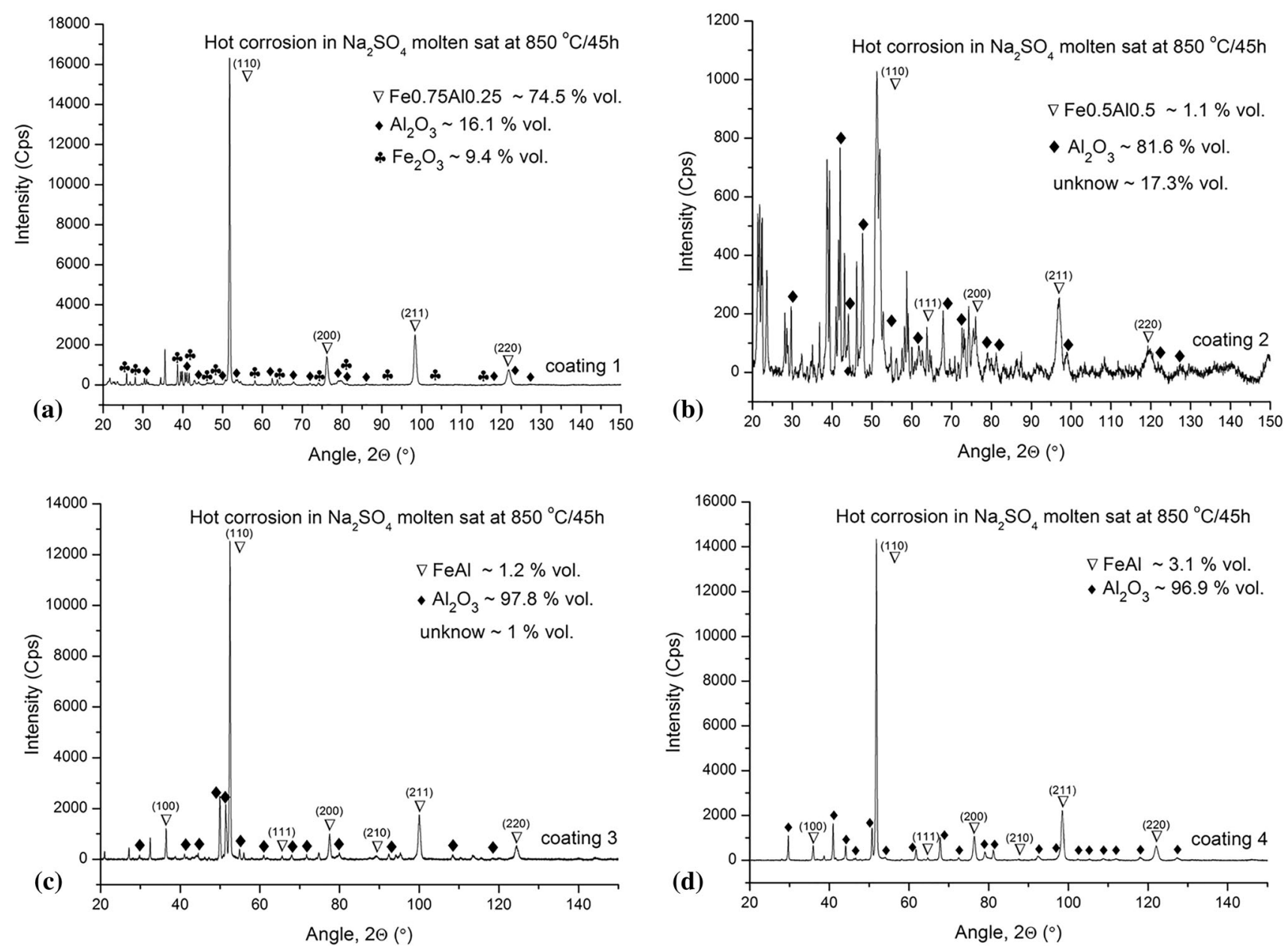

Fig. 11 XRD diffraction patterns of the HVOF coatings after corrosion in molten $\mathrm{Na}_{2} \mathrm{SO}_{4}$ : (a) coating 1, (b) coating 2, (c) coating 3 and (d) coating 4

composition after nine passes of the HVOF gun. At the same time, high plastic deformation of $\mathrm{FeAl}$ grains in the volume of the coating, obtained from the powder particles of different chemical composition with the involvement of alloying elements, proves the plastic deformability of a highly brittle $\mathrm{Fe}-\mathrm{Al}$ phase upon impact with the substrate material. However, significant changes to the percentage shares of iron and aluminum in the structure of the assprayed coatings, involving the oxide phases formed in situ during the HVOF process, indicate melting or pre-melting of the powder particles, coupled with intensive oxidation due to reaction with the highly reactive hydroxyl radicals $(\mathrm{OH})$. Rapid plastic transformation of intermetallic powder particles, combined with their "freezing" in contact with the "cold" substrate, leads to the amorphization of oxide ceramics. The oxides are shaped in the form of flattened, nanometric thin films at the boundaries of the splats, within a fine-dispersed, heterogenous structure of the $\mathrm{Fe}-\mathrm{Al}$ coating. Selective depletion of aluminum, diffusing into oxide phases, has no influence on the behavior of the FeAl
(B2) superstructure, obtained from the pre-milled powder $\mathrm{FeCr} 25+\mathrm{FeAl}-\mathrm{TiAl}-\mathrm{Al}_{2} \mathrm{O}_{3}$ sprayed under applied HVOF conditions. Hard oxide phases, in the form of thin films at the grain boundaries and dispersions in the grain volume, influence the strengthening of the structure, mainly by limiting the dislocation motion and migration of grain boundaries. Consequently, this reduces the susceptibility to plastic deformation of FeAl grains and recrystallization of the intermetallic alloy. Participation of the phases rich in aluminum, namely $\mathrm{Fe}_{2} \mathrm{Al}_{5}$ and $\mathrm{FeAl}_{2}$, as well as oxide phases, leads to the formation of microcracks. As a result, this is conducive to the diffusion of toxic ingredients in aggressive environment of $\mathrm{Na}_{2} \mathrm{SO}_{4}$ molten salt under the conditions of high-temperature oxidation at $850{ }^{\circ} \mathrm{C}$ in the span of $45 \mathrm{~h}$.

Generally, among the multi-phase corrosion products formed on the surface of the $\mathrm{FeAl}$ (HVOF) coatings at the temperature of $850{ }^{\circ} \mathrm{C}$, the dominant oxide is $\alpha-\mathrm{Al}_{2} \mathrm{O}_{3}$, alongside other oxides (i.e., $\mathrm{Fe}_{2} \mathrm{O}_{3}$ ). The aluminum in the Fe-Al coatings is selectively oxidized and forms a stable $\alpha$ - 
$\mathrm{Al}_{2} \mathrm{O}_{3}$ oxide on the surface of the coatings. However, it is then subject to degradation as a result of several structural defects and different thermal expansion coefficients, as compared to the Fe-Al-type phases, especially in the case of the $\mathrm{Fe}_{\mathrm{x}} \mathrm{Al}_{\mathrm{y}}$ coating.

Acknowledgment The research leading to these results has received funding from the People Programme (Accions Marie Curie) of the 7 Framework Programme of the European Union (FP7/2007-2013) under REA Grant Agreement No. 600388 (TECNIO spring programme), and from the Agency for Business Competitiveness of the Government of Catalonia, ACCIÓ. The authors wish to thank Dr. D. Zasada and M.Sc. Eng. D. Marczak from the Department of Advanced Materials and Technologies, Military University of Technology, for his help in the experimental work as well as Prof. L. Swadźba for enabling the study of hot corrosion.

Open Access This article is distributed under the terms of the Creative Commons Attribution 4.0 International License (http://crea tivecommons.org/licenses/by/4.0/), which permits unrestricted use, distribution, and reproduction in any medium, provided you give appropriate credit to the original author(s) and the source, provide a link to the Creative Commons license, and indicate if changes were made.

\section{References}

1. S. Swaminathan, S.-M. Hong, M. Kumar, W.-S. Jung, D.-I. Kim, H. Singh, and I.-S. Choi, Microstructural Evolution and High Temperature Oxidation Characteristics of Cold Sprayed Ni-20Cr Nanostructured Alloy Coating, Surf. Coat. Technol., 2019, 362, p 333-344

2. H. Singh, M. Kaur, and S. Prakash, High-Temperature Exposure Studies of HVOF-Sprayed $\mathrm{Cr}_{3} \mathrm{C}_{2}-25(\mathrm{NiCr}) /(\mathrm{WC}-\mathrm{Co})$ Coating, $J$. Therm. Spray Technol., 2016, 26(6), p 1192-1207

3. N. Kaur, M. Kumar, S.K. Sharma, D. Young Kim, S. Kumar, N.M. Chavan, S.V. Joshi, N. Singh, and H. Singh, Study of Mechanical Properties and High Temperature Oxidation Behavior of a Novel Cold-Spray Ni-20Cr Coating on Boiler Steels, Appl. Surf. Sci., 2015, 328, p 13-25

4. H. Singh, D. Puri, and S. Prakash, An Overview of $\mathrm{Na}_{2} \mathrm{SO}_{4}$ and/ or $\mathrm{V}_{2} \mathrm{O}_{5}$ Induced Hot Corrosion of $\mathrm{Fe}$ - and Ni-Based Superalloys, Rev. Adv. Mater. Sci., 2007, 16(1-2), p 27-50

5. P. Audigié, V. Encinas-Sánchez, M. Juez-Lorenzo, S. Rodríguezo, M. Gutiérrez, F.J. Pérez, and A. Agüero, High Temperature Molten Salt Corrosion Behavior of Aluminide and NickelAluminide Coatings for Heat Storage in Concentrated Solar Power Plants, Surf. Coat. Technol., 2018, 349, p 1148-1157

6. T.L. Talako, M.S. Yakovleva, E.A. Astakhov, and A.I. Letsko, Structure and Properties of Detonation Gun Sprayed Coatings from the Synthesized FeAlSi/ $/ \mathrm{Al}_{2} \mathrm{O}_{3}$ Powder, Surf. Coat. Technol., 2018, 353, p 93-104

7. H.S. Grewal, S. Bhandari, and H. Singh, Parametric Study of Slurry-Erosion of Hydroturbine Steels with and Without Detonation Gun Spray Coatings Using Taguchi Technique, Metall. Mater. Trans. A, 2012, 43A, p 3387-3401

8. R.L. Fleischer, D.M. Dimiduk, and H.A. Lipsitt, Intermetallic Compounds for Strong High-Temperature Materials: Status and Potential, Annu. Rev. Mater. Sci., 1989, 19, p 231-253

9. S.C. Deevi, V.K. Sikka, and C.T. Liu, Processing, Properties and Applications of Nickel and Iron Aluminides, Prog. Mater Sci., 1997, 42, p 177-192
10. Y. Shi and D.B. Lee, Corrosion of Fe3Al-4Cr Alloys at $1000 \mathrm{C}$ in N2-0.1\%H2S Gas, Key Eng. Mater., 2018, 765, p 173-177

11. C. Shen, K.-D. Liss, Z. Pan, Z. Wang, X. Li, and H. Li, Thermal Cycling of $\mathrm{Fe}_{3} \mathrm{Al}$ Based Iron Aluminide During the Wire-Arc Additive Manufacturing Process: An in Situ Neutron Diffraction Study, Intermetallics, 2018, 92, p 101-107

12. W. Liu, Y. Wang, H. Ge, L. Li, Y. Ding, L. Meng, and X. Zhang, Microstructure Evolution and Corrosion Behavior of Fe-Al-Based Intermetallic Aluminide Coatings Under Acidic Condition, Trans. Nonferrous Met. Soc. China, 2018, 28, p 2028-2043

13. S.C. Deevi and V.K. Sikka, Nickel and Iron Aluminides: An Overview on Properties, Processing, and Applications, Intermetallics, 1996, 4, p 357-375

14. D.G. Morris and M.A. Muñoz-Morris, Intermetallics: Past, Present and Future, Rev. Metal., 2005, 41, p 498-501

15. A. Lasalmonie, Intermetallics: Why is it So Difficult to Introduce Them in Gas Turbine Engines?, Intermetallics, 2006, 14, p 11231129

16. V.K. Sikka, Intermetallic-Based High-Temperature Materials, ORNL/CP-101117 (1999), 23 pp

17. C. Xiao and W. Chen, Sulfidation Resistance of $\mathrm{CeO} 2$ Modified HVOF Sprayed FeAl Coatings at $700^{\circ} \mathrm{C}$, Surf. Coat. Technol., 2006, 201, p 3625-3632

18. O.L. Arenas, J. Porcayo-Calderon, V.M. Salinas-Bravo, A. Martinez-Villafane, and J.G. Gonzalez-Rodriguez, Effect of Boron on the Hot Corrosion Resistance of Sprayed Fe40Al Intermetallics, High Temp. Mater. Proc., 2005, 242, p 93-100

19. M.A. Espinosa, G. Carbajal De la Torre, J. Porcayo-Calderon, A. Martinez-Villafañe, J.G. Chacon-Nava, M. Casales, and J.G. Gonzalez-Rodriguez, Corrosion of Atomized Fe40Al Based Intermetallics in Molten $\mathrm{Na}_{2} \mathrm{SO}_{4}$, Mater. Corrosion, 2003, 54, p 304-310

20. J.G. Gonzalez-Rodriguez, M. Salazar Luna-Ramirez, J. PorcayoCalderon, G. Rosas, and A. Martinez-Villfane, Effect of Li, Ce and $\mathrm{Ni}$ on the Corrosion Resistance of $\mathrm{Fe}_{3} \mathrm{Al}$ in Molten $\mathrm{Na}_{2} \mathrm{So}_{4}$ and $\mathrm{NaVO}_{3}$, High Temp. Mater. Proc., 2004, 233, p 17-183

21. M. Amaya, M.A. Espinosa-Medina, J. Porcayo-Calderon, L. Martinez, and J.G. Gonzalez-Rodriguez, High Temperature Corrosion Performance of FeAl Intermetallic Alloys in Molten Salts, Mater. Sci. Eng. A, 2003, 349, p 12-19

22. L. Martinez, M. Amaya, J. Porcayo-Calderon, and E.J. Lavernia, High-Temperature Electrochemical Testing of Spray Atomized and Deposited Iron Aluminides Alloyed with Boron and Reinforced with Alumina Particulate, Mater. Sci. Eng. A, 1998, 258, p 306-312

23. J.G. Gonzalez-Rodriguez, A. Luna-Ramirez, M. Salazar, J. Porcayo-Calderon, G. Rosas, and A. Martinez-Villafane, Molten Salt Corrosion Resistance of FeAl Alloy with Additions of Li, Ce and Ni, Mater. Sci. Eng. A, 2005, 399, p 344-350

24. M.A. Espinosa-Medina, G. Carbajal-De la Torre, H.B. Liu, A. Martínez-Villafane, and J.G. González-Rodriguez, Hot Corrosion Behaviour of $\mathrm{Fe}-\mathrm{Al}$ Based Intermetallic in Molten $\mathrm{NaVO}_{3}$ Salt, Corros. Sci., 2009, 51, p 1420-1427

25. D.K. Goyal, H. Singh, H. Kumar, and V. Sahni, Slurry Erosive Wear Evaluation of HVOF-Spray $\mathrm{Cr}_{2} \mathrm{O}_{3}$ Coating on Some Turbine Steels, J. Therm. Spray Technol., 2012, 21(5), p 838-851

26. C. Senderowski and Z. Bojar, Gas Detonation Spray Forming of Fe-Al Coatings in the Presence of Interlayer, Surf. Coat. Technol., 2008, 202, p 3538-3548

27. J.M. Guilemany, N. Cinca, S. Dosta, and C.R.C. Lima, HighTemperature Oxidation of Fe40Al Coatings Obtained by HVOF Thermal Spray, Intermetallics, 2007, 15, p 1384-1394

28. N. Cinca and J.M. Guilemany, Thermal Spraying of Transition Metal Aluminides: An Overview, Intermetallics, 2012, 24, p 6072 
29. C. Senderowski, Z. Bojar, W. Wołczyński, and A. Pawłowski, Microstructure Characterization of D-Gun Sprayed Fe-Al Intermetallic Coatings, Intermetallics, 2010, 18, p 1405-1409

30. C. Senderowski, M. Chodala, and Z. Bojar, Corrosion Behavior of Detonation Gun Sprayed Fe-Al Type Intermetallic Coating, Materials, 2015, 8, p 1108-1123

31. Y. Tsunekawa, M. Okumiya, K. Gotoh, T. Nakamura, and I. Niimi, Synthesis of Iron Aluminide Matrix In Situ Composites from Elemental Powders by Reactive Low Pressure Plasma Spraying, Mater. Sci. Eng. A, 1992, 159(2), p 253-259

32. S. Wei, B. Xu, H. Wang, G. Jin, and H. Lv, Comparison on Corrosion-Resistance Performance of Electro-Thermal Explosion Plasma Spraying FeAl-Based Coatings, Surf. Coat. Technol., 2007, 201(9-11), p 5294-5297

33. T. Grosdidier, A. Tidu, and H.-L. Liao, Nanocrystalline Fe-40Al Coating Processed by Thermal Spraying of Milled Powder, Scripta Mater., 2001, 44(3), p 387-393

34. G. Ji, J. Morniroli, and T. Grosidider, Nanostructures in Thermal Spray Coatings, Scripta Mater., 2003, 48, p 1599-1604

35. G. Ji, O. Elkedim, and T. Grosdidier, Deposition and Corrosion Resistance of HVOF Sprayed Nanocrystalline Iron Aluminide Coatings, Surf. Coat. Technol., 2005, 190(2), p 406-416

36. B. Szczucka-Lasota, B. Formanek, and A. Hernas, Growth of Corrosion Products on Thermally Sprayed Coatings with Intermetallic Phases in Aggressive Environments, J. Mater. Process. Technol., 2005, 164-165, p 930-934

37. B. Szczucka-Lasota, B. Formanek, A. Hernas, and K. Szymański, Oxidation Models of the Growth of Corrosion Products on the Intermetallic Coatings Strengthened by a Fine Dispersive $\mathrm{Al}_{2} \mathrm{O}_{3}$, J. Mater. Process. Technol., 2005, 164-165, p 935-939

38. Y. Wang and M. Yan, The effect of $\mathrm{CeO}_{2}$ on the Erosion and Abrasive Wear of Thermal Sprayed FeAl Intermetallic Alloy Coatings, Wear, 2006, 261(11-12), p 1201-1207

39. T. Grosdidier, G. Ji, F. Bernard, E. Gaffet, Z.A. Munir, and S. Launois, Synthesis of Bulk FeAl Nanostructured Materials by HVOF Spray Forming and Spark Plasma Sintering, Intermetallics, 2006, 14, p 1208-1213

40. G. Ji, T. Grosdidier, and J.-P. Morniroli, Microstructure of a High-Velocity Oxy-Fuel Thermal-Sprayed Nanostructured Coating Obtained from Milled Powder, Metall. Mater. Trans. A, 2007, 38(10), p 2455-2463

41. G. Ji, T. Grosdidier, N. Bozzolo, and S. Launois, The Mechanisms of Microstructure Formation in a Nanostructured Oxide Dispersion Strengthened FeAl Alloy Obtained by Spark Plasma Sintering, Intermetallics, 2007, 15, p 108-118

42. G. Ji, T. Grosdidier, F. Bernard, S. Paris, E. Gaffet, and S. Launois, Bulk FeAl Nanostructured Materials Obtained by Spray Forming and Spark Plasma Sintering, J. Alloy. Compd., 2007, 434-435, p 358-361

43. J.M. Guilemany, C.R.C. Lima, N. Cinca, and J.R. Miguel, Studies of Fe-40Al Coatings Obtained by High Velocity Oxy-Fuel, Surf. Coat. Technol., 2006, 201, p 2072-2079

44. J.M. Guilemany, N. Cinca, J. Fernández, and S. Sampath, Erosion, Abrasive, and Friction Wear Behavior of Iron Aluminide Coatings Sprayed by HVOF, J. Therm. Spray Technol., 2008, 17(5-6), p 762-773

45. J.M. Guilemany, N. Cinca, S. Dosta, and I.G. Cano, FeAl and $\mathrm{NbAl}_{3}$ Intermetallic-HVOF Coatings: Structure and Properties, $J$. Therm. Spray Technol., 2009, 18(4), p 536-545

46. N. Cinca, S. Dosta, and J.M. Guilemany, Nanoscale Characterization of FeAl-HVOF Coatings, Surf. Coat. Technol., 2010, 205, p $967-973$

47. J. Xiang, X. Zhu, G. Chen, Z. Duan, Y. Lin, and Y. Liu, Oxidation Behavior of Fe40Al-xWC Composite Coatings Obtained by High-Velocity Oxygen Fuel Thermal Spray, Trans. Nonferrous Met. Soc. China, 2009, 19, p 1545-1550
48. L. Singh, V. Chawla, and J.S. Grewal, A Review of Detonation Gun Sprayed Coatings, J. Miner. Mater. Charact. Eng., 2012, 11(3), p 243-265

49. C. Senderowski, Z. Bojar, W. Wołczyński, G. Roy, and T. Czujko, Residual Stresses Determined by the Modified Sachs Method Within a Gas Detonation Sprayed Coatings of the Fe-Al Intermetallic, Arch. Metall. Mater., 2007, 52(4), p 569-578

50. C. Senderowski and Z. Bojar, Influence of Detonation Gun Spraying Conditions on the Quality of Fe-Al Intermetallic Protective Coatings in the Presence of $\mathrm{NiAl}$ and $\mathrm{NiCr}$ Interlayers, $J$. Therm. Spray Technol., 2009, 18(3), p 435-447

51. A. Pawłowski, T. Czeppe, Ł. Major, and C. Senderowski, Structure Morphology of Fe-Al Coating Detonation Sprayed Onto Carbon Steel Substrate, Arch. Metall. Mater., 2009, 54(3), p 783-788

52. W. Wołczyński, C. Senderowski, J. Morgiel, and G. Garzeł, D-Gun Sprayed Fe-Al Single Particle Solidification, Arch. Metall. Mater., 2014, 59(1), p 209-217

53. C. Senderowski, A. Pawłowski, Z. Bojar, W. Wołczyński, M. Faryna, J. Morgiel, and Ł. Major, TEM Microstructure of Fe-Al Coatings Detonation Sprayed Onto Steel Substrate, Arch. Metall. Mater., 2010, 55(2), p 373-381

54. A. Pawłowski, C. Senderowski, Z. Bojar, and M. Faryna, Detonation Deposited Fe-Al Coatings, Part I: The Interlayers Ni(Al) and $\mathrm{Ni}(\mathrm{Cr})$ and $\mathrm{Fe}-\mathrm{Al}$ Coating Detonation Sprayed onto Substrate of 045 Steel, Arch. Metall. Mater., 2010, 55(4), p 1061-1071

55. A. Pawłowski, C. Senderowski, W. Wołczyński, and J. Morgiel, Detonation Deposited Fe-Al Coatings, Part II: Transmission Electron Microscopy of Interlayers and Fe-Al Intermetallic Coating Detonation Sprayed onto the 045 Steel Substrate, Arch. Metall. Mater., 2011, 56(1), p 71-79

56. C. Senderowski, Nanocomposite Fe-Al Intermetallic Coating Obtained by Gas Detonation Spraying of Milled Self-Decomposing Powder, J. Therm. Spray Technol., 2014, 237, p 11241134

57. C. Senderowski, D. Zasada, T. Durejko, and Z. Bojar, Characterization of As-Synthesized and Mechanically Milled Fe-Al Powders Produced by the Self-Disintegration Method, Powder Technol., 2014, 263, p 96-103

58. B. Fikus, C. Senderowski, and A. Panas, Modeling of Dynamics and Thermal History of Fe40Al Intermetallic Powder Particles Under Gas Detonation Spraying Using Propane-Air Mixture, $J$. Therm. Spray Technol., 2019, 28, p 346-358

59. A.J. Panas, C. Senderowski, and B. Fikus, Thermophysical Properties of Multiphase Fe-Al Intermetallic-Oxide Ceramic Coatings Deposited by Gas Detonation Spraying, Thermochim. Acta, 2019, 676, p 164-171

60. B. Xu, Z. Zhu, S. Ma, W. Zhang, and W. Liu, Sliding Wear Behavior of $\mathrm{Fe}-\mathrm{Al}$ and $\mathrm{Fe}-\mathrm{Al} / \mathrm{WC}$ Coatings Prepared by High Velocity Arc Spraying, Wear, 2004, 257, p 1089-1095

61. T.C. Totemeier, R.N. Wright, Coating-microstructure-propertyperformance issues, in 19th Annual Conference on Fossil Energy Materials, INL/CON-05-00416, Preprint (2005), 9 pp

62. A. Magnee, E. Offergeld, M. Leroy, A. Lefort, Fe-Al intermetallic coating applications to thermal energy conversion advanced systems, in Proceedings of the 15th Thermal Spray Conference, Nice (France), vol. 2 (1998), pp. 1091-1096

63. B.S. Sidhu and S. Prakash, Evaluation of the Corrosion Behaviour of Plasma-Sprayed $\mathrm{Ni}_{3} \mathrm{Al}$ Coatings on Steel in Oxidation and Molten Salt Environments at $900^{\circ} \mathrm{C}$, Surf. Coat. Technol., 2003, 166, p 89-100

64. G.D. Girolamo, C. Blasi, M. Schioppa, and L. Tapfer, Structure and Thermal Properties of Heat Treated Plasma Sprayed CeriaYttria Co-stabilized Zirconia Coatings, Ceram. Int., 2010, 36, p 961-968 
65. R.L. Jones, Some Aspects of the Hot Corrosion of Thermal Barrier Coatings, J. Therm. Spray Technol., 1997, 61, p 77-84

66. X. Chen, Y. Zhao, L. Gu, B. Zou, Y. Wang, and X. Cao, Hot Corrosion Behavior of Plasma Sprayed YSZ/LaMgAl ${ }_{11} \mathrm{O}_{19}$ Composite Coatings in Molten Sulfate-Vanadate Salt, Corros. Sci., 2011, 53, p 2335-2343

67. R. Ahmadi-Pidani, R. Shoja-Razavi, R. Mozafarinia, and H. Jamali, Evaluation of Hot Corrosion Behavior of Plasma Sprayed Ceria and Yttria Stabilized Zirconia Thermal Barrier Coatings in the Presence of $\mathrm{Na}_{2} \mathrm{SO}_{4}-\mathrm{V}_{2} \mathrm{O}_{5}$ Molten Salt, Ceram. Int., 2012, 38, p 6613-6620

68. X.H. Zhong, Y.M. Wang, Z.H. Xu, Y.F. Zhang, J.F. Zhang, and X.Q. Cao, Hot-Corrosion Behaviors of Overlay-Clad Yttria-Stabilized Zirconia Coatings in Contact with Vanadate-Sulfate Salts, J. Eur. Ceram. Soc., 2010, 30, p 1401-1408

69. T.S. Sidhu, R.D. Agrawal, and S. Prakash, Hot Corrosion of Some Superalloys and Role of High-Velocity Oxy-Fuel Spray Coatings-A Review, Surf. Coat. Technol., 2005, 198, p 441-446

70. T.C. Totemeier, R.N. Wright, and W.D. Swank, Microstructure and Stresses in HVOF Sprayed Iron Aluminide Coatings, $J$. Therm. Spray Technol., 2002, 113, p 400-408

71. T.C. Totemeier, R.N. Wright, and W.D. Swank, FeAl and Mo-SiB Intermetallic Coatings Prepared by Thermal Spraying, Intermetallics, 2004, 12, p 1335-1344

72. G. Ji, J.P. Morniroli, A. Tidu, C. Coddet, and T. Grosdidier, Surface Engineering by Thermal Spraying Nanocrystalline Coatings: X-Ray and TEM Characterisation of As-Deposited Iron Aluminide Structure, J. Phys. IV France, 2002, 12(6), p 509-518

73. G. Ji, T. Grosdidier, H.L. Liao, J.-P. Morniroli, and C. Coddet, Spray Forming Thick Nanostructured and Microstructured FeAl Deposits, Intermetallics, 2005, 13, p 596-607

74. T. Grosdidier, G. Ji, and N. Bozzolo, Hardness, Thermal Stability and Yttrium Distribution in Nanostructured Deposits Obtained by Thermal Spraying from Milled $-\mathrm{Y}_{2} \mathrm{O}_{3}$ Reinforced-or Atomized FeAl Powders, Intermetallics, 2006, 14(7), p 715-721

75. M.A. Uusitalo, P.M.J. Vuoristo, and T.A. Mantyla, High Temperature Corrosion of Coatings and Boiler Steels in Reducing Chlorine-Containing Atmosphere, Surf. Coat. Technol., 2002, 161, p 275-285

76. S. Kamal, R. Jayaganthan, S. Prakash, and S. Kumar, Hot Corrosion Behavior of Detonation Gun Sprayed Cr3C2-NiCr Coatings on $\mathrm{Ni}$ and Fe-Based Superalloys in Na2SO4-60\% V2O5 Environment at $900{ }^{\circ} \mathrm{C}, \mathrm{J}$. Alloys Compd., 2008, 463, p 358-372
77. A.Y. Mosbah, D. Wexler, and A. Calka, Abrasive Wear of WCFeAl Composites, Wear, 2005, 258, p 1337-1341

78. M. Ahmadian, D. Wexler, T. Chandra, and A. Calka, Abrasive Wear of WCeFeAl-B and $\mathrm{WCeNi}_{3} \mathrm{Al}-\mathrm{B}$ Composites, Int. J. Refract. Met. Hard Mater., 2005, 23, p 155-159

79. B.-H. Tian, P. Liu, B.-S. Xu, S.-N. Ma, W. Zhang, and S.-Z. Li, Tribological Properties of Thermal Spray Formed $\mathrm{Fe}_{3} \mathrm{Al}$-Based Coatings at Elevated Temperature, Chin. J. Nonferrous Met., 2003, 13, p 978-982

80. M. Sozańska, B. Kościelniak, and L. Swadźba, Evaluation of Hot Corrosion Resistance of Directionally Solidified Nickel-Based Superalloy, Solid State Phenom., 2015, 227, p 337-340

81. K. Katiki, S. Yadlapati, S.N.S. Chidepudi, and N. Arivazhagan, Performance of Plasma Spray Coatings on Inconel 625 in Air Oxidation and Molten Salt Environment at $800^{\circ} \mathrm{C}$, Int. J. Chem. Teach. Res., 2014, 65, p 2744-2749

82. C. Senderowski, Iron-Aluminium Intermetallic Coatings Synthesized by Supersonic Stream Metallization, Copyright by BEL Studio Sp. Z o.o., Warszawa-2015 (2015). ISBN: 978-83-7798227-3. $280 \mathrm{pp}$ (in polish)

83. J.M. Guilemany, N. Cinca, S. Dosta, Oxidation Behavior of HVOF-Sprayed ODS-Fe $40 \mathrm{Al}$ Coatings at $900^{\circ} \mathrm{C}$, in Proceedings of Thermal Spray (Global Coating Solutions, 2007)

84. K. Natesan, Corrosion Performance of Iron Aluminides in MixedOxidant Environments, Mater. Sci. Eng., 1998, 2581-2, p 126134

85. A. Mignone, S. Frangini, A. La Barbera, and O. Tassa, High Temperature Corrosion of B2 Iron Aluminides, Corros. Sci., 1998, 408, p 1331-1347

86. Metals Handbook, High Temperature Corrosion in Molten Salts, Vol 13, 9th ed., ASM International, Russell Township, 1987, p 50-55

87. J.C. Hallet and K.H. Stern, Vaporization and Decomposition of $\mathrm{Na}_{2} \mathrm{SO}_{4}$. Thermodynamics and Kinetics, J. Phys. Chem., 1980, 84, p 1699-1704

88. M. Amaya, M.A. Espinosa-Medina, J. Porcayo-Calderon, L. Martinex, and J.G. Gonzalex-Rodriguez, High Temperature Corrosion Performance of FeAl Intermetallic Alloys in Molten Salts, Mater. Sic. Eng. A, 2003, 349, p 12-19

Publisher's Note Springer Nature remains neutral with regard to jurisdictional claims in published maps and institutional affiliations. 